Portland State University

PDXScholar

6-8-2001

\title{
The Neoglacial History of Mt. Thielsen, Southern Oregon Cascades
}

Martin Dietrich Lafrenz

Portland State University

Follow this and additional works at: https://pdxscholar.library.pdx.edu/open_access_etds

Part of the Geography Commons

Let us know how access to this document benefits you.

\section{Recommended Citation}

Lafrenz, Martin Dietrich, "The Neoglacial History of Mt. Thielsen, Southern Oregon Cascades" (2001).

Dissertations and Theses. Paper 2429.

https://doi.org/10.15760/etd.2426

This Thesis is brought to you for free and open access. It has been accepted for inclusion in Dissertations and Theses by an authorized administrator of PDXScholar. For more information, please contact pdxscholar@pdx.edu. 


\section{THESIS APPROVAL}

The abstract and thesis of Martin Dietrich Lafrenz for the Master of Science in

Geography were presented June 8,2001 , and accepted by the thesis committee and the department.

COMMTTTEE APPROVALS:

Keith S. Hadley, Chair

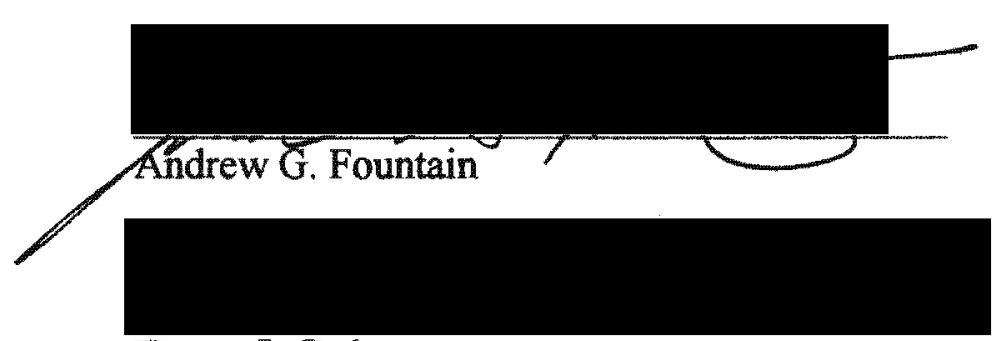

Teresa L. Bulman

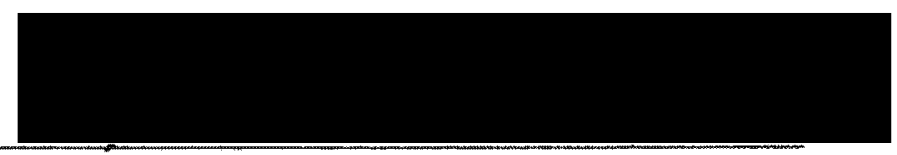

Scott F. Burns

Representative of the Office of Graduate Studies

DEPARTMENT APPROVAL:

Teresa L. Bulman, Chair

Department of Geography 


\begin{abstract}
An abstract of the thesis of Martin Dietrich Lafrenz for the Master of Science in Geography presented June 8, 2001.
\end{abstract}

Title: The Neoglacial History of Mt. Thielsen, Southern Oregon Cascades.

Little Ice Age (LIA) deposits are recognized on Mt. Thielsen, southern Oregon Cascades $\left(43^{\circ} 9^{\prime} \mathrm{N}, 122^{\circ} 3^{\prime} \mathrm{W}\right.$ ), based on particle morphology and relative position. The initial advance, Lathrop 1, created a sharp-crested moraine and a protalus rampart within $200 \mathrm{~m}$ of the headwall. The retreat of the glacier and recent ice movement, Lathrop 2, is recognized by the deformation of the moraine and a mantle of "protalus till" creating a polygenetic "push-deformation" moraine. Both the moraine and the protalus rampart have sparse vegetation, no lichens, and a lightly weathered $\mathrm{Cox} / \mathrm{C}$ soil. This sequence is correlative with LIA Phase 1 and Phase 2 on Mt. Jefferson, central Oregon Cascades, and is broadly correlated with LIA deposits throughout the Cascades, Sierra Nevada, and Rocky Mountains.

There is no evidence for pre-LIA deposits at Mt. Thielsen. The ELA on Lathrop Glacier ( $2450 \mathrm{~m}$ ) is lower than ELAs on nearby glaciers. The glacier probably exists because of its preferential topographic position and extensive debris cover; thus, if annual snowfall decreases the glacier will persist longer than a similar 
sized bare ice glacier. Conversely, a growing protalus rampart may indicate an increase in annual snowfall but not necessarily a decrease in annual temperatures. The lack of older Neoglacial deposits on Mt. Thielsen may be a result of insufficient snowfall to maintain or advance the Lathrop Glacier. As such, the LIA may represent a period when climatic conditions were more severe than at any other time in the Neoglacial.

Boulder size, shape, and orientation proved useful for classifying geomorphic features and assessing the relative ages of slopes. However, soils are the best method for correlating deposits in the cirque with other locations. Soils beyond the moraine are developed in Mazama ash and have moderately developed Bw horizons, depth to weathering over $70 \mathrm{~cm}$, and Harden's PDI for B horizons of 2.10-3.64. Soils are Typic Vitricryands. 
THE NEOGLACIAL HISTORY OF MT. THIELSEN, SOUTHERN OREGON CASCADES

by

MARTIN DIETRICH LAFRENZ

A thesis submitted in partial fulfillment of the requirements for the degree of

\section{MASTER OF SCIENCE \\ in \\ GEOGRAPHY}

Portland State University

2001 


\section{ACKNOWLEDGEMENTS}

This project and entire degree program would never have happened without the support of my wife, Chris. For her patience and perseverance (particularly with the endless trips up and down that trail), I am eternally indebted. I also received invaluable support from my dedicated field assistants Jeff Lafrenz, Wally Lafrenz, Pat Studley, Marc Weber, Deb Tolman, Craig Revels, Kelly Pohl, and Jim Labbe (I am sorry most of you did not get to see the site without six inches of snow cover)! I would like to thank my committee for their helpful advice and critiques of my manuscripts. Their guidance kept my "learning experience" from becoming more experience than learning. Finally, I am most grateful to my advisor, Keith Hadley, for not only his assistance on this project, but for the hours of theoretical geomorphology discussions that were at best tangentially associated with this thesis. His earnest interest in my academic and professional development is truly a credit to his commitment to students. 


\section{TABLE OF CONTENTS}

\section{PAGE}

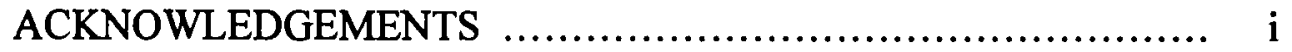

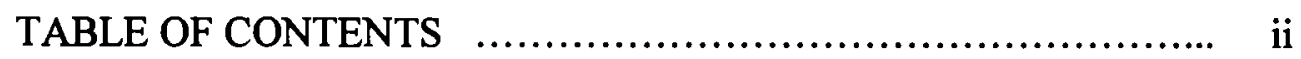

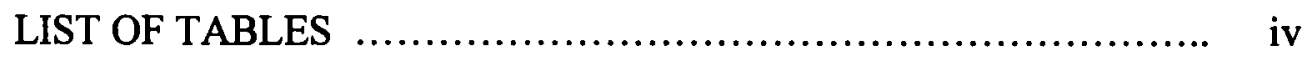

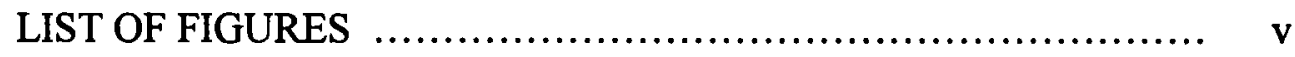

INTRODUCTION E.................................................

Holocene climate and the Neoglacial $\ldots \ldots \ldots \ldots \ldots \ldots \ldots \ldots \ldots . . \ldots \ldots$

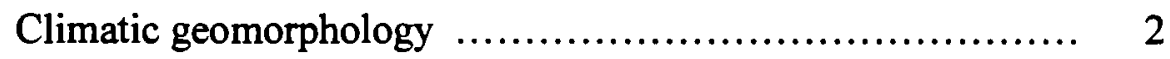

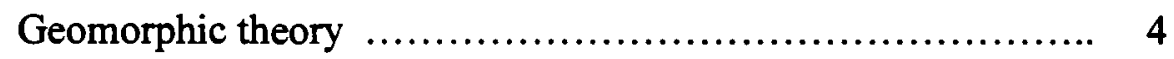

LITERATURE REVIEW [........................................ 6

The Neoglacial in the western United States $\ldots \ldots \ldots \ldots \ldots \ldots \ldots . \ldots$

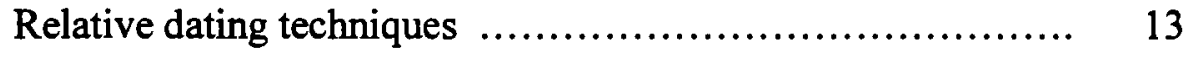

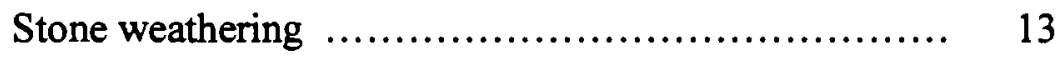

Lichenometry ..................................... 15

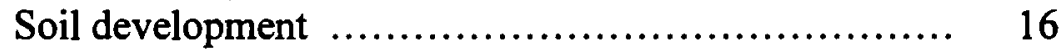

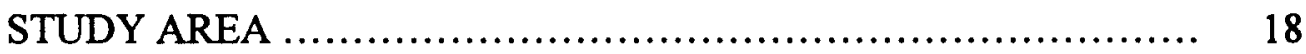

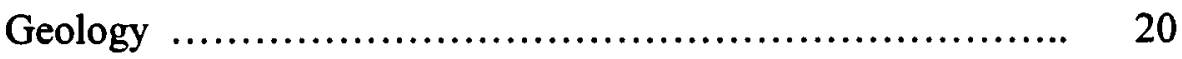

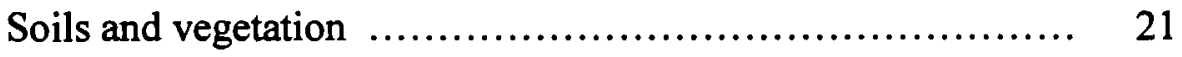

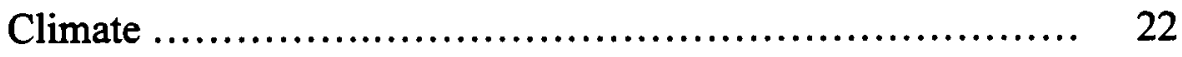

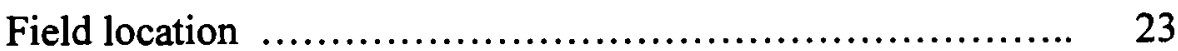




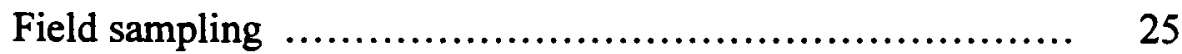

Stone weathering measurements and lichenometry $\ldots . . . \quad 26$

Particle size and orientation measurements ............. 27

Transect sampling ....................................... 27

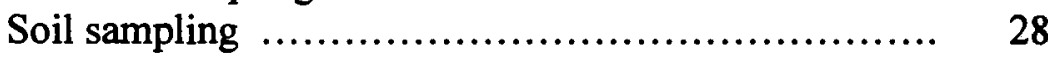

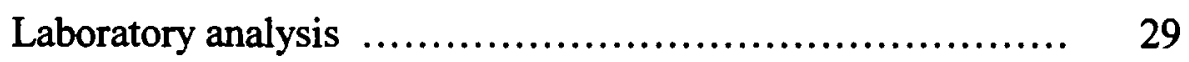

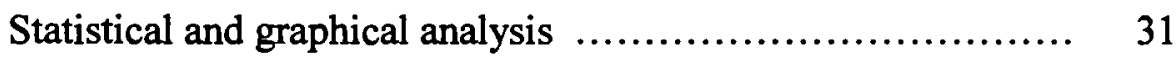

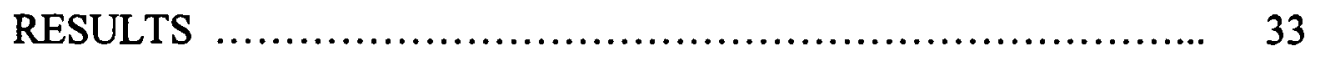

Weathering characteristics and lichenometry ................. 33

Boulder size and orientation ................................... 35

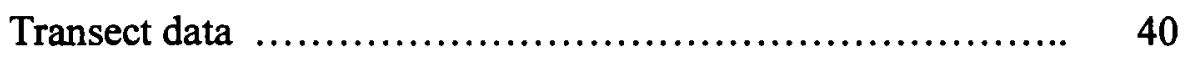

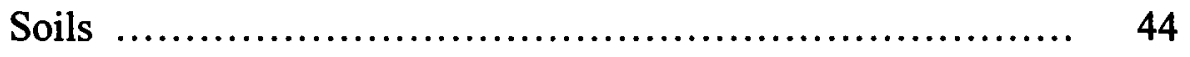

DISCUSSION ............................................. 50

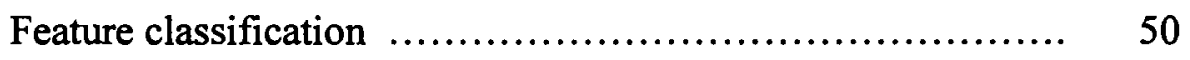

Distinctions between moraines and protalus ramparts .. 50

Rock Island Features $\ldots \ldots \ldots \ldots \ldots \ldots \ldots \ldots \ldots \ldots \ldots \ldots . . \ldots \ldots$

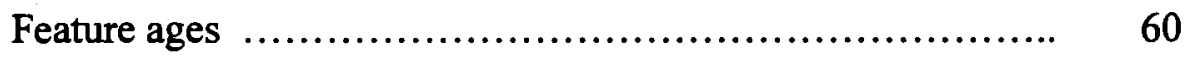

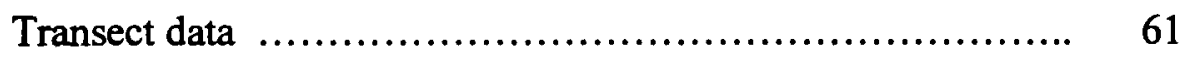

Comparison of deposits and methods $\ldots \ldots \ldots \ldots \ldots \ldots \ldots \ldots \ldots . . \ldots 3$

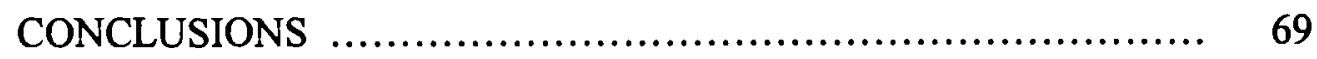

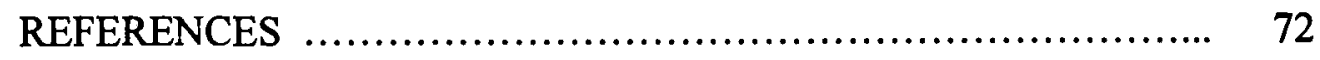




\section{LIST OF TABLES}

$\begin{array}{lll}\text { TABLE } & \text { PAGE }\end{array}$

I Timing and correlation of Neoglacial advances in the western United States

II - Weathering characteristics and lichenometry for features in the north cirque of Mt. Thielsen .............. 36

III Boulder sizes for features in the study area ............. 38

IV Boulder orientations for features in the study area ...... 40

V Boulder sizes and lichenometry for transect sections .... 42

VI Boulder shape characteristics for transect sections ..... 43

VII Boulder orientations for transect sections ............... 44

VIII Weathering characteristics and soil development indices for soils in the cirque ......................... 45

IX Particle size data for soils in the study area ............. 49

$\mathrm{X}$ Relative dating results from Neoglacial studies in the Cascade Range .................................. 65 


\section{LIST OF FIGURES}

FIGURE

PAGE

1. Location map of the central and southern Oregon

Cascades

2. North face of Mt. Thielsen and the Lathrop Glacier ....

19

3. Monthly mean precipitation (ppt) and mean temperature

(temp) for Crater Lake National Park, Oregon

$(1975 \mathrm{~m}) 60 \mathrm{~km}$ south of the Mt. Thielsen study

area (Western Regional Climate Center, 1999) ...

4. Talus features in the north cirque of Mt. Thielsen ....... 24

5. Locations of sample plots and transect .................. 26

6. Map of glacial and periglacial features on

Mt. Thielsen

34

7. Median and range of values for $\mathrm{A}$ axis boulder lengths of talus features $1-8$

8. Rose diagrams of boulder orientations in plots grouped in $15^{\circ}$ sections

9. Median and range of values for $\mathrm{A}$ axis boulder lengths by section 
10. Rose diagrams of boulder orientations in transect grouped

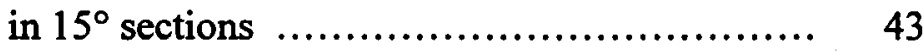

11. Soil profile for rock island $8 \ldots \ldots \ldots \ldots \ldots \ldots \ldots \ldots \ldots . \ldots . \ldots . \ldots$

12. Soil profile for rock island $7 \ldots \ldots \ldots \ldots \ldots \ldots \ldots \ldots . . . . \ldots$

13. Moraine and glacier mantled with protalus till ........ 53

14. Protalus rampart adjacent to the moraine

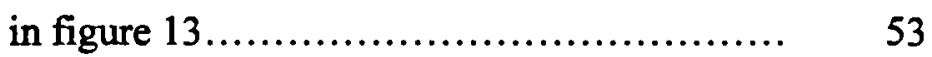

15. Typical impact scars found on rock island

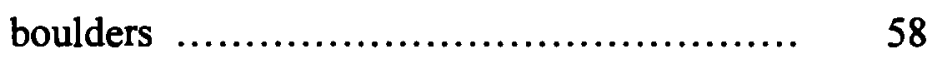

16. Tree on rock island topped by rockfall.................. 58

17. Stand of trees possibly topped by a slab avalanche .... 59 


\section{CHAPTER I}

\section{INTRODUCTION}

The purpose of this paper is to describe the Neoglacial history of Mt. Thielsen in the southern Oregon Cascades, place the study area in the context of other Neoglacial chronologies throughout the western cordillera, and to assess the effectiveness of several relative dating techniques. Like many alpine cirques in western North America, the north face of Mt. Thielsen has glacial and periglacial features nested up-valley from the terminal position of Pleistocene glaciers. Geomorphic features in these locations typically lack organic material above treeline suitable for carbon 14 dating. As a result, relative dating techniques are used including those based on weathering and botanical indicators to determine the timing of glacial advances and to separate the various geomorphic features into their respective climatic episodes. This exercise has not been previously done for Mt. Thielsen and, several of the relative dating techniques had yet to be employed in the Oregon Cascades.

\section{HOLOCENE CLIMATE AND THE NEOGLACIAL}

Ice core data show average global temperatures during the last glacial maximum (18,000 YBP) were as much as $8^{\circ} \mathrm{C}$ cooler than today (Petit et al., 1999). Warming temperatures caused the retreat of both continental ice sheets and alpine 
glaciers until a brief cooling period of $2-4^{\circ} \mathrm{C}$, the Younger Dryas (c.a. $11,000-12,000$ YBP) (Mangerud, 1987; O'Brien, et al., 1995), when many alpine glaciers readvanced (Davis, 1988). Following the Younger Dryas, temperatures were highly variable in the northern hemisphere but mostly warmer than today (Alley et al., 1999). There was another brief cooling period (7800-8800 YBP) (O'Brien, et al., 1995), followed by an abrupt transition into the warm and dry Altithermal (Antevs, 1955) that lasted from 6100-7800 YBP (O'Brien, et al., 1995). During the Altithermal, it is presumed that all alpine glaciers in the western cordillera completely ablated (Burke and Birkeland, 1983).

The Neoglacial is a climatic classification describing a period of relative cooling since the Altithermal (Porter and Denton, 1967; Denton and Karlen, 1973). Beginning 6100 YBP temperatures decreased (Petit, et al., 1999), and by 5000 YBP cirque glaciers re-appeared in many alpine areas of the American cordillera (Davis, 1988). Temperature variation throughout the Neoglacial has been high (O'Brien, et al., 1995) but has stayed within $2^{\circ} \mathrm{C}$ of today. Consequently, these alpine glaciers have advanced and retreated numerous times in different locations.

\section{CLIMATIC GEOMORPHOLOGY}

Slight modifications in annual temperature or precipitation are sufficient to create glacial or periglacial features in alpine areas (Büdel, 1982). This dynamic influence of climate on landform evolution forms the basis of climatic geomorphology. It has also been shown that a change in regional climate affects the 
behavior of glaciers in alpine areas (e.g., McCabe et al., 2000). Thus, identifying and assigning relative ages to glacial and periglacial features are a means of reconstructing glacial activity in a cirque and, ultimately, recognizing changes in the regional climate for that area. However, it is important to identify the processes that lead to the development of landforms in order to avoid erroneous classifications and hence, incorrect reconstructions of past climate.

Because north-facing cirques are shaded from direct sunlight for much of the year, these areas tend to have the greatest number of Neoglacial features (Graf, 1976). Terminal moraines in theses cirques mark the extent of any recent glacial advance. Where rock accumulation is greater than snow accumulation and mean annual temperatures are particularly low, a rock glacier (Washburn, 1980) or debris-covered glacier (Clark et al., 1994) may develop. Where the opposite conditions occur, snow accumulation exceeds rock accumulation but temperatures are not low enough to maintain a glacier, a protalus rampart may develop (Washburn, 1980). A protalus rampart forms as material tumbles or slides across a permanent snowfield and accumulates at its base. As the snow depth decreases, a rock wall is left that usually continues to collect rockfall debris. Both of these features remain long after temperatures have warmed, and the glaciers or snowfields have disappeared. Thus, identification of these features indicates a past climate that was colder and/or wetter. 


\section{GEOMORPHIC THEORY}

Quaternary reconstruction depends on the proper classification of features and an understanding of the spatial and temporal distribution of the landforms throughout the study area. Chamberlain (1897) warned of becoming too wed to a particular landform interpretation; he advised researchers to maintain "multiple working hypotheses" (p. 838), "to bring up into view every rational explanation of the phenomenon in hand" (p. 843), and to develop rigorous tests for those hypotheses. This is no trivial matter when attempting to describe the process that led to the existence of a particular landform.

The misinterpretation of landforms and resultant problems of describing geomorphic change are well described by Schumm (1991). Of particular interest to this study are the problems of convergence and divergence. Convergence refers to different processes producing similar effects; conversely, divergence refers to similar causes producing different effects (Schumm, 1991). The talus-derived features on Mt. Thielsen must, therefore, be properly classified if they are to be successfully employed as indicators of regional climate change.

It is vital to define scale with any study in the earth sciences. Schumm and Lichty (1965) note the importance of both time and space with the study of any geomorphic system. For example, rockfall is a short-duration event that occurs over a relatively small area. However, each rockfall event is a function of processes occurring at larger scales including tectonic activity, climatic variability, and high 
magnitude mass wasting events. Since the retreat of Wisconsin glaciers, the dominant large scale and regional processes in the Oregon Cascades have been climate change and volcanism.

The glacial and periglacial features in the north cirque on Mt. Thielsen have formed over hundreds of years and cover spatial scales of tens to hundreds of meters. Meentemeyer (1989) argues that any geographic inquiry must be concerned with events happening at spatial and temporal scales above and below the area of interest. Thus, my analysis includes recognition of regional climate change and volcanism since the end of the Pleistocene as well as the effects of rockfall, seasonal temperature change, and precipitation variability.

The Washington Cascades and the Sierra Nevada Mountains have been well documented with regard to Neoglacial histories. The southern Oregon Cascades are transitional spatially and possibly climatically between these two areas. Therefore, the Neoglacial history at Mt. Thielsen adds to an understanding of climate change throughout the Holocene by showing to what extent climate change is spatially synchronous or only regionally significant. 


\section{CHAPTER II}

\section{LITERATURE REVIEW}

Several studies describe Neoglacial features found in alpine areas of the western United States (Table I). These studies have consistently used relative dating techniques to assign ages to these features and to correlate Neoglacial chronologies. Nonetheless, a complete picture of the Neoglacial in the western cordillera remains elusive because of incomplete coverage across the region and the lack of universally applicable dating methods. There is a particular need to describe Neoglacial chronologies in Oregon and to determine which relative dating techniques are applicable in the Oregon Cascades.

\section{THE NEOGLACIAL IN THE WESTERN UNITED STATES}

The majority of Holocene glacial studies have been done in the Rocky Mountains of Colorado (Table I). Many cirques in the Front Range have been investigated at least once, and some have been repeatedly described and debated (Mahaney, 1973a, 1973b; Williams, 1973). The Neoglacial history of this area was initially described in three distinct phases based on soil development, stone weathering, and lichenometry as Triple Lakes (5000-3500 YBP), Audubon (25001500 YBP), and Arapaho Peak (500 ypb to present) representing early and middle Neoglacial and the Little Ice Age respectively (Benedict, 1973). 
More recently, radiocarbon dates from lake-bottom sediments upvalley of the type locality Triple Lakes inner moraine revealed the moraine was at least 10,000 years old and thus, late Pleistocene in age (Davis and Osbourne, 1987). Davis (1988) suggests a new type locality and name is necessary for the remaining deposits thought to be of early Neoglacial age in addition to collecting more radiocarbon dates before attempting to correlate these deposits with other areas.

Neoglacial chronologies for Wyoming and Idaho (Table I) have also been described with three distinct phases, Indian Basin, Audubon, and Gannett Peak representing the early and middle Neoglacial and the Little Ice Age (Mahaney and Spence, 1984; Butler et al., 1984). Although these deposits were initially correlated with the Colorado chronosequence, Davis (1988) argues the Indian Basin deposits may not actually be associated with the radiocarbon date used by Mahaney and Spence (1984). Therefore, some of the Indian Basin deposits may be late Pleistocene in age. Although recent studies have also reported three distinct sets of Neoglacial deposits (Hall, 1994; Odell and Hopkins, 1995), the age and timing of the Neoglacial sequence for all Rocky Mountain sites still requires better age controls before it can be determined whether there is truly a three-fold Neoglacial sequence. 


\section{TABLE I}

TIMING AND CORRELATION OF NEOGLACIAL ADVANCES IN THE WESTERN UNITED STATES

(Items in quotes are older than the date shown-see text)

\begin{tabular}{|c|c|c|c|c|c|c|c|}
\hline \multirow[b]{2}{*}{$\begin{array}{r}\text { Years } \\
\text { BP }\end{array}$} & \multicolumn{7}{|c|}{ Rocky Mountains } \\
\hline & $\begin{array}{l}\text { Front Range, } \\
\text { CO (southem) }\end{array}$ & $\begin{array}{l}\text { Front Range, } \\
\mathrm{CO} \text { (central) }{ }^{2}\end{array}$ & $\begin{array}{c}\text { Sawatch Range, } \\
\mathrm{CO}^{3}\end{array}$ & $\begin{array}{c}\text { Teton and } \\
\text { Wind River } \\
\text { Ranges, WY }\end{array}$ & $\begin{array}{l}\text { Lemhi Mtns., } \\
\text { ID }^{5}\end{array}$ & $\begin{array}{c}\text { Wasatch Range, } \\
\mathrm{UT}^{6}\end{array}$ & $\begin{array}{c}\text { La Sal } \\
\text { Mtns., UT }{ }^{7}\end{array}$ \\
\hline 100 & & & & & & Little Ice & $\overline{\text { Upper Gold }}$ \\
\hline 500 & Arapaho Peak & Gannett Peak & Gannett Peak & Gannett Peak & Gannett Peak & Age & Basin \\
\hline 1000 & & & & & & & \\
\hline 1500 & & & & & & & "b" \\
\hline 2000 & & & Audobon & Audobon & & & Lower Gold \\
\hline 2500 & Audobon & Audobon & & & Audobon & & Basin \\
\hline 3000 & & & & & & & "a" \\
\hline 3500 & & & "Temple Lake II" & & & & \\
\hline 4000 & & & \& & & & Early Neoglacial & \\
\hline 4500 & & & "Temple Lake I" & & & & \\
\hline 5000 & "Triple Lakes" & "Temple Lake" & & "Indian Basin" & "Indian & & \\
\hline
\end{tabular}

(1-Benedict, 1968 and 1973; 2-Mahaney, 1973a, Odell and Hopkins, 1995; 3-Miller, 1973; 4-Mahaney and Spence, 1984, Hall, 1994; 5- Butler, 1988; 6-Madsen and Currey, 1979, Anderson and Anderson, 1981; 7-Richmond, 1962) 
TABLE I

TIMING AND CORRELATION OF NEOGLACIAL ADVANCES IN THE WESTERN UNITED STATES (Items in quotes are older than the date shown-see text)

(continued)

\begin{tabular}{|c|c|c|c|c|c|c|c|}
\hline \multirow[b]{2}{*}{$\begin{array}{l}\text { Years } \\
\text { BP }\end{array}$} & \multicolumn{2}{|c|}{ Sierra Nevada } & \multicolumn{2}{|c|}{ California Cascades } & \multicolumn{3}{|c|}{ Southern Oregon Cascades } \\
\hline & $\begin{array}{l}\text { Recess area } \\
\text { (northern) }\end{array}$ & $\begin{array}{l}\text { Recess area } \\
\text { (northern) }\end{array}$ & $\begin{array}{c}\text { Mt. Shasta, } \\
\text { CA }^{10}\end{array}$ & $\begin{array}{c}\text { Lassen Peak, } \\
\mathrm{CA}^{*}{ }^{11}\end{array}$ & $\begin{array}{l}\text { Mt. McLoughlin, } \\
\text { OR }^{12}\end{array}$ & $\begin{array}{l}\text { Mt. Bachelor, } \\
\text { OR }^{13}\end{array}$ & $\begin{array}{c}\text { Broken } \\
\text { Top/Three } \\
\text { Sisters, OR }{ }^{14}\end{array}$ \\
\hline 100 & & & & & & $\overline{\text { Little Ice }}$ & Little Ice \\
\hline 500 & Matthes & Matthes & unnamed & & Neoglaciation II & Age & Age \\
\hline 1000 & & & & & & & \\
\hline 1500 & & & & & & & \\
\hline 2000 & & & & & & & \\
\hline 2500 & & unnamed early & & & & & \\
\hline 3000 & & Neoglacial & & & & Early & Early \\
\hline 3500 & & & & & Neoglaciation I & Neoglacial & Neoglacial \\
\hline 4000 & & & & *No Neoglacial & & & \\
\hline 4500 & "Recess Peak" & "Recess Peak" & & deposits & & & \\
\hline 5000 & 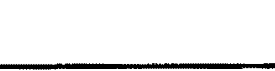 & & & & & & \\
\hline
\end{tabular}


TABLE I

TIMING AND CORRELATION OF NEOGLACIAL ADVANCES IN THE WESTERN UNITED STATES (Items in quotes are older than the date shown-see text)

(continued)

\begin{tabular}{|c|c|c|c|c|c|c|c|}
\hline \multicolumn{3}{|c|}{ Oregon } & Eastern Oregon & \multicolumn{3}{|c|}{ Washington Cascades } & \multirow[b]{2}{*}{$\begin{array}{c}\text { Mt. Baker, } \\
\text { WA }^{21}\end{array}$} \\
\hline $\begin{array}{r}\text { Years } \\
\text { BP }\end{array}$ & $\begin{array}{l}\text { Mt Jefferson, } \\
\text { OR }^{15}\end{array}$ & $\begin{array}{l}\text { Mt. Hood, } \\
\text { OR }^{16}\end{array}$ & $\begin{array}{c}\text { Wallowa } \\
\text { Mountains, OR }{ }^{17}\end{array}$ & $\begin{array}{c}\text { Mount Adams, } \\
\text { WA }^{18}\end{array}$ & $\begin{array}{l}\text { Mt. Rainier, } \\
\text { WA }^{19}\end{array}$ & $\begin{array}{c}\text { Dome Peak, } \\
\text { WA }^{20}\end{array}$ & \\
\hline 100 & Jefferson Park & Little Ice & & I & Gorda & Little Ice & Little Ice \\
\hline 500 & I \& II & Age & Eagle Cap & II & Stade & Age & Age \\
\hline \multicolumn{8}{|l|}{1000} \\
\hline \multicolumn{8}{|l|}{1500} \\
\hline 2000 & & & Prospect Lake & & & & \\
\hline \multicolumn{8}{|l|}{2500} \\
\hline 3000 & & & & & Burroughs & & \\
\hline 3500 & & & & III & Stade & & \\
\hline \multicolumn{8}{|l|}{4000} \\
\hline 4500 & & Early & & & & Early & \\
\hline 5000 & & Neoglacial (?) & & & & Neoglacial & \\
\hline
\end{tabular}


Until recently, there also appeared to be three Neoglacial phases in the Sierra Nevada Mountains. The Recess Peak, unnamed phase, and Matthes were thought to correlate with the original Rocky Mountain chronology (Yount et al., 1979; Burke and Birkeland, 1983). However, radiocarbon ages from basal lake sediments behind a type Recess Peak moraine were at least 11,000 years old (Clark and Gillespie, 1997) and therefore, late Pleistocene in age. Lichenometry and sediment cores from rock glaciers in the Sierra Nevada suggest there was, however, at least one pre-Little Ice Age advance beginning about 3000 years ago (Konrad and Clark, 1998).

In the Washington Cascades the Neoglacial chronology is complex (Table I). There is evidence for an early Neoglacial advance on Dome Peak (Miller, 1969) but not on Mt. Baker (Burrows, et al., 2000); each site has Little Ice age deposits but lack the equivalent to a middle Neoglacial advance. Conversely, evidence for an early Neoglacial advance is lacking for Mt. Rainier (Crandell and Miller, 1974) and Mt. Adams (Mahaney et al., 1981), although their middle Neoglacial deposits have not been positively dated (Heine, 1998). Since Holocene volcanism has been an important geomorphic agent in the Washington Cascades, landslides and eruptions may have influenced the development of some Neoglacial features and complicated the Neoglacial chronologies.

Neoglacial deposits are found in both the Cascade Range and the Wallowas in Oregon (Table I). The Wallowas have evidence for middle Neoglacial and Little Ice Age advances (Prospect Lake and Eagle Cap respectively); however, there is no till representing the early Neoglacial (Kiver, 1974). Deposits older than Little Ice Age are 
not well dated in the Oregon Cascades. Sharp crested moraines on Mt. McLoughlin (Carver, 1972) and Broken Top (Dethier, 1980) may predate the Little Ice Age based on tephra layers and weathering characteristics, but it is not clear if they correlate with the middle or early Neoglacial advances in other regions.

Mt. Hood has numerous moraines from the Little Ice Age and a series of deposits with moderate soil development described as recessional Pleistocene moraines (Lilliquist, 1989); however, Mazama ash is lacking in these soil profiles, and they may be Neoglacial deposits. Mt. Jefferson (Scott, 1977) has two sets of Little Ice Age deposits, Phase 1 and Phase 2, but lacks sufficient weathering on the Phase 1 deposits to classify them as either middle or early Neoglacial.

Scott and Gardner (1990) describe a partially buried moraine on Mt. Bachelor that appears, based on weathering characteristics, to be older than Little Ice Age. They suggest the Little Ice Age event was the most extensive of any Neoglacial advance in the Oregon Cascades and may have obliterated evidence of earlier glacial activity. Mt. Lassen, in the California Cascades, lacks Neoglacial features (Crandell, 1970). Yet, these features may have been buried by an early $20^{\text {th }}$ century eruption. Any "missing" Neoglacial features in the Cascades could thus have been obliterated by more recent glaciation or mantled by volcanic debris. The talus-derived features on Mt. Thielsen serve as a good test case for these arguments. The volcano is located between Broken Top and Mt. McLoughlin and should have deposits similar to those two mountains. It is relatively small has been inactive throughout the Holocene 
(Sherrod, 1990). Thus, it would require a significant change in climate in order to sustain a glacier, and the resultant landforms should still be visible.

\section{RELATIVE DATING TECHNIQUES}

Topographic and stratigraphic position of glacial and periglacial features continues to be the best relative age indicator. As a glacier advances, it radically alters the landscape and incorporates material both sub-glacially and supra-glacially (Easterbrook, 1993). This process either destroys or cross-cuts any older moraines while marking the extent of that particular glacial advance. Thus, the furthest down valley or buried moraine represents the oldest glacial advance in that area.

The relative position of a glacial feature does not by itself indicate how much older or younger a feature is from other features in the cirque. Blackwelder (1931) recognized this and developed a suite of relative dating techniques to separate moraines into different glacial advances. His method was to establish $100 \mathrm{ft} \times 20 \mathrm{ft}$ plots on the crest of each moraine in the study area and to assess the degree of surface stone weathering in each plot. His methods were refined and by Nelson (1954) and Sharp (1969) and ultimately standardized by Birkeland (1973).

\section{Stone Weathering}

Surface stones begin to weather immediately after deposition. Stone weathering, particularly oxidation, occurs first on the surface of a clast and then progresses toward the interior (Nelson, 1954). The result of weathering is a 
weakening and discoloration of the stone from the exterior layer toward its center. This discoloration is identified as a weathering rind, and it is particularly well pronounced on basalt and andesite stones (Porter, 1975). The thickness of a stone weathering rind has been shown to correlate well with the age of that feature (Birkeland, 1973; Porter, 1975; Colman and Pierce, 1984). Collections of cobblesized stones ( $7.5-25 \mathrm{~cm}$ in diameter) from a particular feature's surface are broken with a rock hammer and the width of any observed weathering rinds are recorded. Weathering rinds up to $14 \mathrm{~mm}$ thick have been reported for granitic Neoglacial deposits in Colorado (Birkeland, 1973), but andesitic deposits of similar age in the Washington Cascades have a maximum rind thickness of $4 \mathrm{~mm}$ (Mahaney et al., 1981). Nevertheless, in all areas, cobbles with relatively thicker weathering rinds indicate a relatively older age for that feature.

The percentage of fresh to weathered boulders $(>30 \mathrm{~cm}$ diameter) is another indicator of the relative age of a feature. This abrasion ratio, where a weathered stone has no trace of its original color or texture, is expressed as a percentage of fresh boulders on the surface of a feature (Sharp, 1969; Mahaney et al., 1981). Neoglacial features in Colorado have $100 \%$ fresh stones on young deposits and up to $73 \%$ fresh stones on the oldest Neoglacial features (Birkeland, 1973). Deposits in the Washington Cascades range from $100 \%$ fresh stones on recent moraines to $96 \%$ fresh stones on the oldest features (Mahaney et al., 1981).

The stone weathering technique used most often is frequency of surface boulders. This technique assumes the number of exposed boulders is inversely related 
to the age of the feature since boulders tend to break down and be buried over time (Sharp, 1969). Relatively lower boulder frequencies represent relatively older deposits. Most researchers use the Blackwelder (1931) plot dimension converted to metric, $10 \mathrm{~m} \times 6 \mathrm{~m}$, and report the frequency of surface boulders per unit area. Values for Neoglacial deposits range from 60 per $100 \mathrm{~m}^{2}$ on the youngest features to 30 per $100 \mathrm{~m}^{2}$ on the oldest in the Washington Cascades (Mahaney et al., 1981). Values exceeding 100 boulders per $100 \mathrm{~m}^{2}$ have been reported for Little Ice Age deposits in central Oregon (Scott, 1977).

\section{Lichenometry}

Beschel (1958) pioneered the use of lichens as an indicator of the age for a geomorphic surface. Researchers in Europe and western North America have had success using crustose lichens to assign both absolute and relative ages to features in alpine areas based on lichen thalli diameter (Benedict, 1967, 1968; Matthews, 1994). In most studies, the sub-species Rhizocarpon geographicum is used because of its slow growth, distinctive appearance, and ubiquitous occurrence above treeline (Benedict, 1968).

Lichens begin growing on a feature's exposed rock substrate shortly after stabilization. This technique of lichenometry assumes that the largest lichen thalli on a feature represent the timing of deposition or stabilization (Beschel, 1958). By measuring a suitable sample of lichens (at least 30 ) on various features, one assigns relative ages to features based on the maximum thalli diameters and the mean of the 
five largest lichen diameters (Innes, 1984). This technique is usually restricted to areas above treeline, and the lichens should be roughly circular, should not have coalesced, and should have similar substrates (Beschel, 1958). The percentage of a boulder's surface covered by lichen should also increase over time (Benedict, 1968). Lichens that have coalesced will preclude accurate measures of lichen thallus. The maximum age that can be assessed using lichenometry in the Oregon Cascades is not known, as the technique has only been used on Little Ice Age features.

\section{$\underline{\text { Soil Development }}$}

Descriptions of soil development are particularly useful for assessing the relative ages of Neoglacial features. Soil development is a function of climate, biota, relief, parent material, and time (Jenny, 1941). Thus, if factors other than time are near constant, soil development will indicate the relative timing of glacial deposition. Good indicators of soil development include horizon thickness, texture, structure, color, and particle size distribution (Birkeland, 1999).

Controlling for parent material is the most difficult challenge when comparing soils from different cirque locations. This can be problematic in volcanic areas that exhibit markedly different accumulations of ash, tephra, and colluvium between adjacent volcanoes. Some authors (e.g., Haugland, 1998) have found different parent material for soils in the same study area.

Under these circumstances, relative soil development is best compared using a soil development index. Harden's (1982) profile development index (PDI) measures 
the amount a horizon has been altered from its original parent material as a result of pedogenesis. It is calculated by describing various qualities of the soil profile, assessing the same qualities in the parent material (or some suitable proxy of the parent material), and assigning 10 points for each degree of pedogenic change in the soil. This total is then divided by current world maximum of possible change to normalize the value.

Higher PDI values represent relatively advanced soil development. The values for each category of soil development within each horizon (e.g., texture, structure, consistence, presence of clay films) are summed, divided by the number of categories used, and multiplied by the thickness of that horizon. The PDI values can be combined for all horizons in a profile, but it is more common to report PDIs from only the B horizons (Birkeland, 1999) as the B horizon best represents pedogenesis. Since Mt. Thielsen is an extinct volcano (Sherrod, 1990), the surface deposits should be relatively stable. Therefore, Mt. Thielsen is an ideal location for using surface weathering features and soil development as a means of constructing a Neoglacial chronology. 


\section{CHAPTER III}

\section{STUDY AREA}

Mt. Thielsen $\left(43^{\circ} 9^{\prime} \mathrm{N}, 122^{\circ} 3^{\prime} \mathrm{W}\right)$ stands at $2,799 \mathrm{~m}$ in the southern Oregon Cascades $60 \mathrm{~km}$ north of Crater Lake (Figure 1). Mt. Thielsen (Figure 2) is a highly eroded composite volcano with a jagged narrow pyroclastic cone resting on a broad base of older lava (Sherrod, 1990). Successive Pleistocene glaciations have exposed colorful layers of pyroclastic lava that dip steeply away from the central plug; the resulting shape, a classic horn, led to it initially being described as the "Matterhorn" of Oregon (Williams, 1933 p. 195). Mt. Thielsen is also called the "lighting rod of the Cascades" (Williams, 1933 p. 195) because of the abundant fulgurites, small tubes of brownish black to olive-black glassy rock fused from other rock by a lightning strike, found within $5 \mathrm{~m}$ of its craggy summit (Purdom, 1966).

Mt. Thielsen has been inactive for at least 290,000 years (Sherrod, 1990), and was heavily eroded by Quaternary glaciations. Sharp arêtes separate cirques on the northeast and west faces of the mountain. Lathrop Glacier, the southern-most glacier in Oregon (Anonymous, 1981), occupies the upper portion of the north-facing cirque. Using an accumulation-area ratio of 0.65 (Meier and Post, 1962), the current equilibrium line altitude (ELA) for Lathrop Glacier is approximately $2450 \mathrm{~m}$. This is somewhat lower than the ELAs reported for glaciers on nearby Broken Top and the Three Sisters volcanoes (Dethier, 1980). 


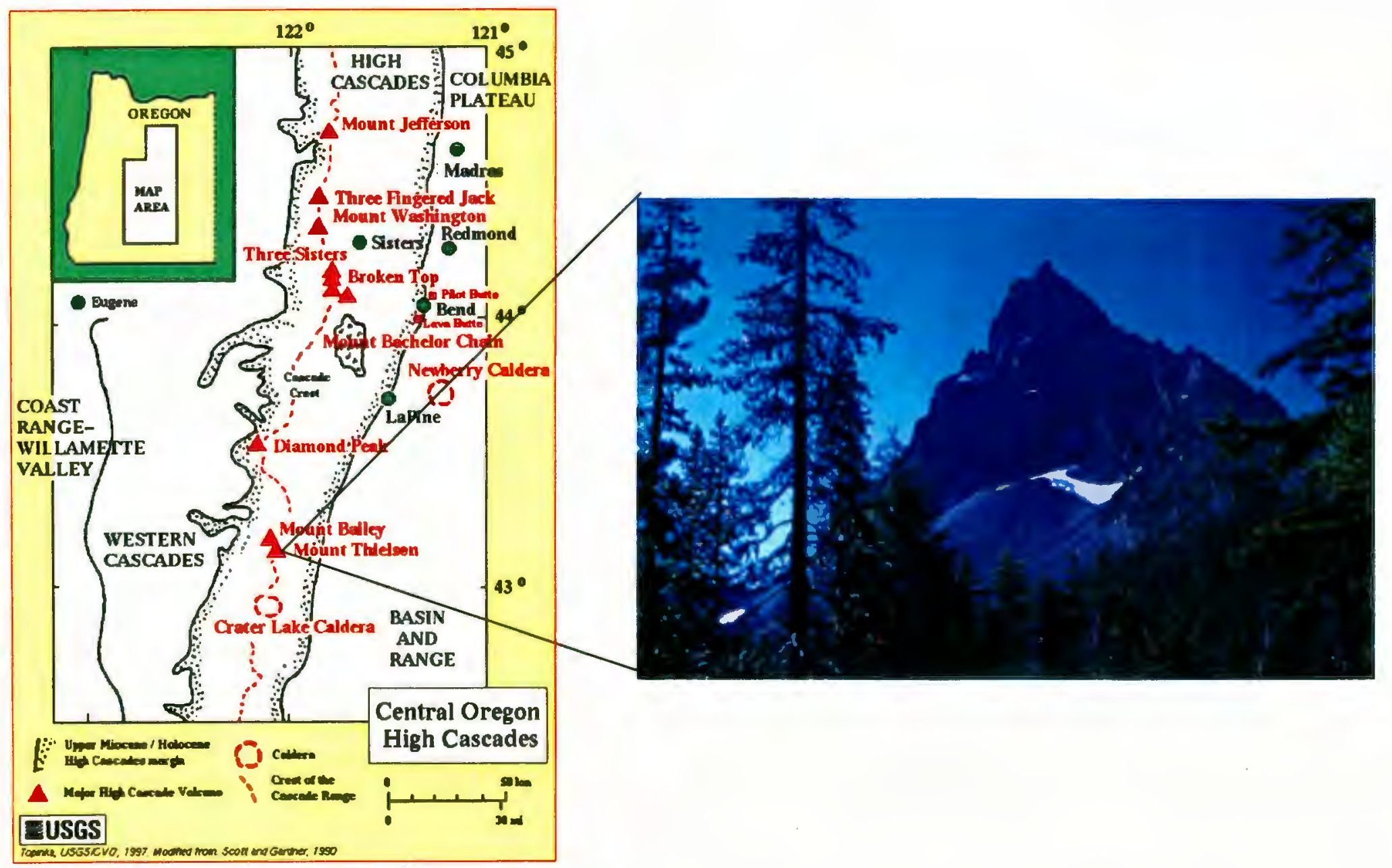

Figure 1: Location map of the central and southern Oregon Cascades.

Figure 2: North face of Mt. Thielsen and the Lathrop Glacier. 


\section{GEOLOGY}

Mt. Thielsen is a relatively old member of the High Cascade Range of volcanoes that trend north-south from British Columbia to northern California. The range is composed of volcanic rock that erupted in the upper Miocene and throughout the Quaternary forming a broad platform of shield volcanoes and cinder cones along the east margin of the older Miocene Western Cascades (Taylor, 1981). Basalt constitutes $85 \%$ of the High Cascades by volume although dacite and rhyodacite can be locally important (Orr and Orr, 1999). Most volcanoes in the range have been active throughout the Quaternary. However, volcanic activity is less frequent and more andesitic at each end of the chain (i.e., British Columbia and southern Oregon (Orr and Orr, 1999).

Mt. Thielsen probably became active in the early Pliocene (Williams, 1933). The base of the mountain formed slowly as fluid basalt poured from a central vent and later from fissures further down the mountain's flank (Williams, 1933). The shield reached a maximum elevation of approximately $3000 \mathrm{~m}$ (Williams, 1933) before the lavas forming Mt. Thielsen became more silica rich, highly viscous, and explosive (Nafziger, 1974). This new stage of development formed the central pyroclastic cone. The cone consists of scoriaceous to pumiceous cindery tuff and coarse breccia interlaced with basalt dikes. The beds dip $10-40^{\circ}$ away from the central plug; the steeper angles formed during the intrusion of the central plug (Sherrod, 1990).

The lower flanks of Mt. Thielsen are buried by 4-20 $\mathrm{m}$ of ash (Sherrod, 1990) from the catastrophic eruption of Mt. Mazama 6,800 YBP (Bacon, 1983). On steep 
slopes the ash quickly eroded, and at higher elevations mass wasting has buried the ash deposits. The resulting surficial deposits below treeline (approximately $1,800 \mathrm{~m}$ ) consist of ash and glacial till. In the cirques, surface deposits include coarse fragments of andesite, basalt, breccia, pumice, and ash.

The extent of glaciation in the Mt. Thielsen area during the last major glacial advance is poorly documented. However, it is broadly assumed that an ice cap covered the Cascade volcanoes in Oregon from $30 \mathrm{~km}$ north of Mt. Jefferson down to Mt. McLouglin, south of Mt. Thielsen (Crandell, 1969). Scott (1977) has dated the glacial deposits from Mt. Jefferson to Mt. Washington and correlated the last major glacial advance, type locality Cabot Creek, with the Fraser advance in Washington (ending approximately 11,000 YBP). Terminal moraines representing these advances lie several kilometers down valley from current glacier positions.

\section{SOILS AND VEGETATION}

Soils in the Mt. Thielsen area are relatively young. Since the flanks of the mountain were probably glaciated until 11,000 YBP, there has been little time for soil development in the sub-alpine region. As mentioned, the entire area was buried with ash from the Mazama eruption. Below treeline, areas without significant ash deposits support an old-growth mountain hemlock (Tsuga mertensiana) forest. Soils on stable sites with deep ash accumulations support stunted and sparse stands of lodgepole pine (Pinus contorta). In both cases, soils are moderately developed Typic Vitricryands (Soil Survey Staff, 1999). 
Cirque soils on Mt. Thielsen are poorly developed Typic Vitricryands (Soil Survey Staff, 1999) where there was a significant re-deposition of ash. These areas support krumholz mountain hemlock. Talus accumulations in the cirque have no soil development and only sparse shrubs and herbaceous vegetation.

\section{CLIMATE}

The nearest climate station to Mt. Thielsen is Crater Lake National Park, Oregon $(1975 \mathrm{~m})$. Mean annual temperature is $3^{\circ} \mathrm{C}$, and mean annual precipitation is $166 \mathrm{~cm}$ (Western Regional Climate Center, 1999). Summers are cool with average July temperatures of $12^{\circ} \mathrm{C}$ (Figure 3); summer monthly precipitation totals are $5-7 \mathrm{~cm}$ occurring mostly as thundershowers with occasional snow in early June or late August. Winter temperatures are lowest in December and January, averaging $-3^{\circ} \mathrm{C}$. Precipitation is highest in November and December with monthly snowfall totals of 27 $\mathrm{cm}$ snow water equivalent. The period of record mean annual precipitation is 1361 $\mathrm{cm}$. Snow patches often linger in high elevation forest areas into September. 


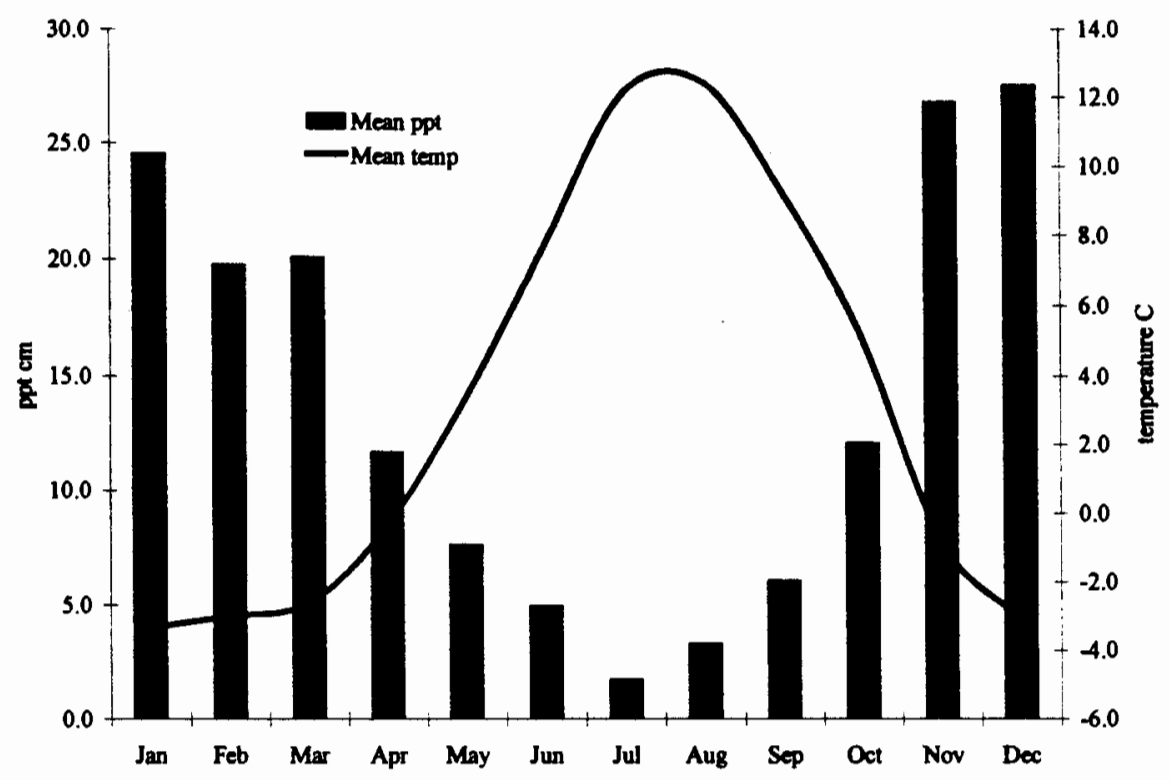

Figure 3: Monthly mean precipitation (ppt) and mean temperature (temp) for Crater Lake National Park, Oregon (1975 m) $60 \mathrm{~km}$ south of the Mt. Thielsen study area (Western Regional Climate Center, 1999).

\section{FIELD LOCATION}

Data for this project were collected in the north cirque of Mt. Thielsen. The cirque is mostly above the local treeline and is dominated by talus accumulation (Figure 4). The Lathrop Glacier is located at the top of the cirque and occupies two steep couloirs directly beneath the summit spire (Figure 2). Immediately in front of the glacier are massive accumulations of talus and morainal debris (Figure 4). A colorful talus slope demarcates the western wall of the cirque, and the eastern boundary has been incised by Thielsen Creek (Figure 4). The northern cirque limit is defined by a transition to the buff-brown colored of Mazama ash and treeline. 


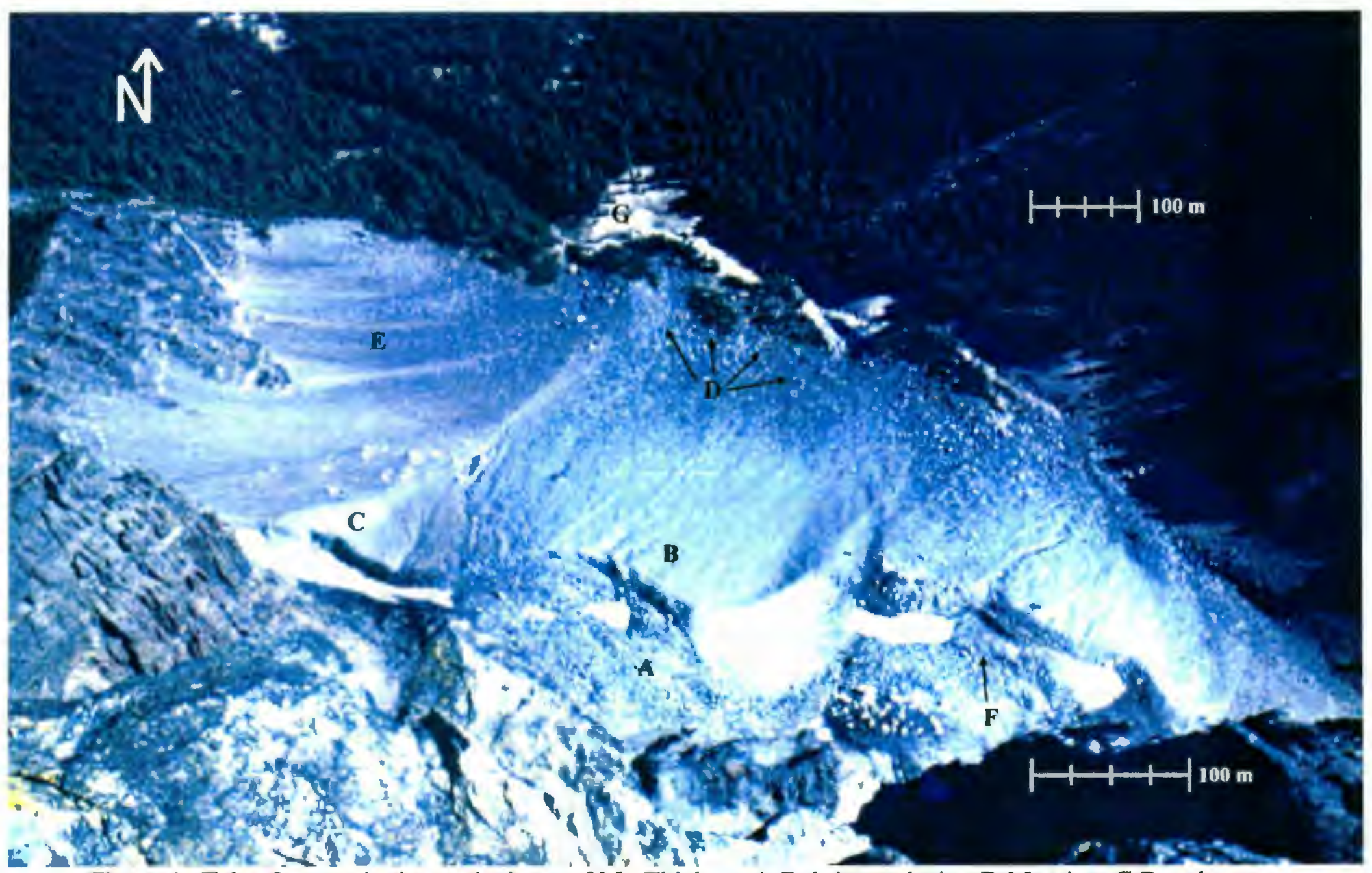

Figure 4. Talus features in the north cirque of Mt. Thielsen: A-Debris on glacier; B-Moraine; C-Protalus rampart; D-Rock islands; E-Talus slope; F-Tarn draining to Thielsen Creek; G-Mazama ash. 


\section{CHAPTER IV}

\section{METHODS}

I described Neoglacial features in the north cirque of Mt. Thielsen using largesize particle analyses, measurement of feature slope angles and relative position to the glacier headwall, boulder surface weathering, lichenometry, soil profile descriptions, and tephra distribution. Field data collected using these methods were plotted, mapped, and statistically analyzed for feature classification and hypothesis testing.

\section{FIELD SAMPLING}

Sample sites were initially identified using United States Forest Service 1:6000 aerial photographs. I identified several possible glacial or periglacial features including moraine-type features immediately in front of Lathrop Glacier and an older dissected deposit at the base of the cirque (Figure 4).

Following techniques established by Blackwelder (1931), with recommendations from Birkeland et al. (1971), I located eight plots, one each on the proximal and distal side of the talus feature fronting the glacier in two different locations (Figure 5, Plots 1-4) and one on each of the four rock islands that constitute the dissected deposit at the base of the cirque (Figure 5, Plots 5-8). I sampled each feature using $6 \times 30 \mathrm{~m}$ plots placed near the feature crest and oriented along the feature's long axis. Within each plot I sampled using several relative dating methods 
and recorded boulder morphology to gain insight into both the age of the feature as well as the usefulness of the various relative dating and morphometric techniques.

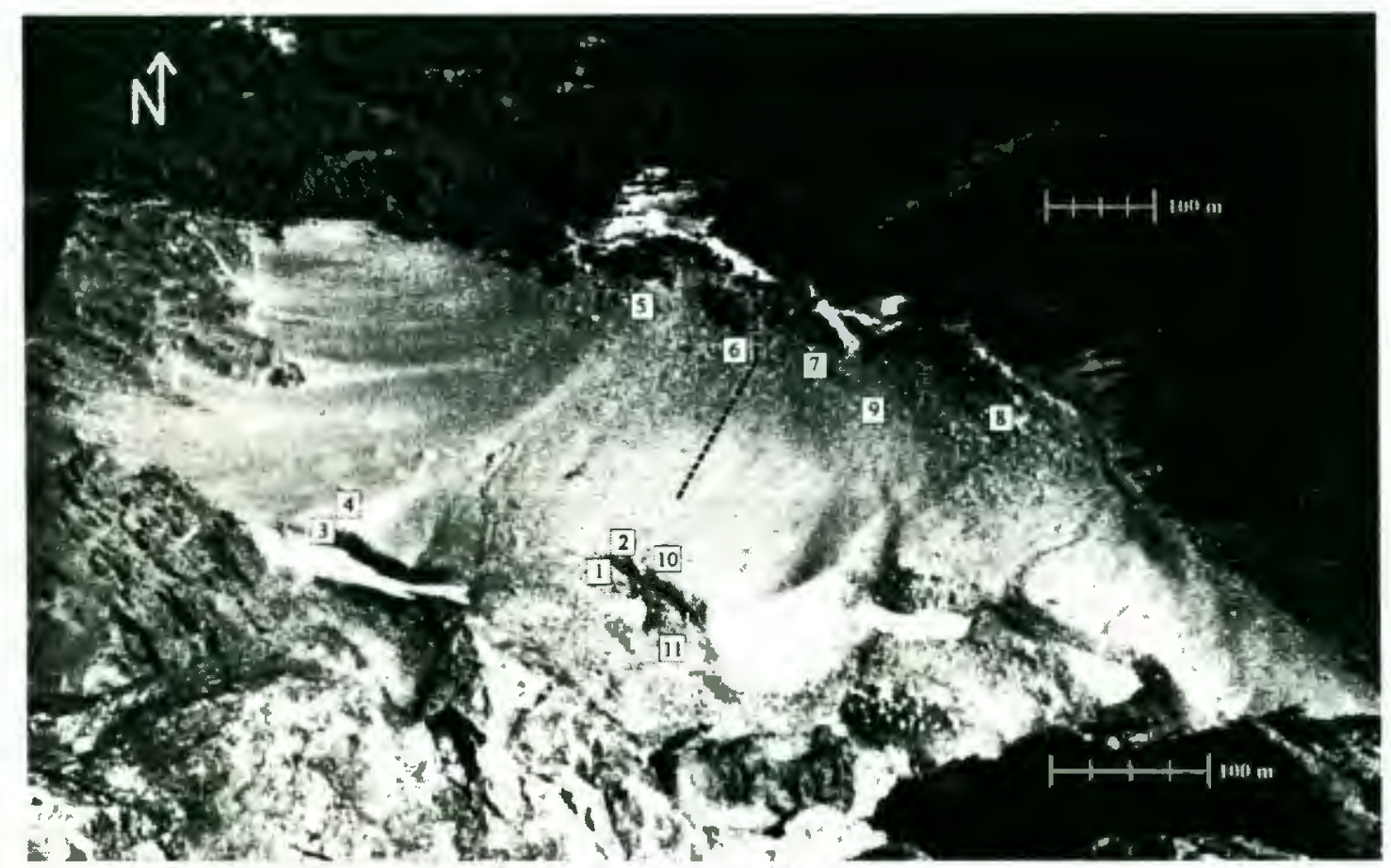

Figure 5: Locations of sample plots and transect.

Stone Weathering Measurements and Lichenometry

I inspected 50 boulders $(\geq 30 \mathrm{~cm}$ diameter) in each plot to determine degree of surface weathering (Sharp, 1969) and percent lichen cover (Benedict, 1968). Surface weathering estimates, the abrasion ratios, were calculated using a fresh-to-weathered ratio (Blackwelder, 1931) where a weathered stone has no trace of its original fresh surface (Mahaney et al., 1981). Any lichens encountered were noted and the diameters of $R$. geographicum lichen thalli were measured to the nearest millimeter.

Within each plot, I selected 50 andesitic cobbles $(7.5-25 \mathrm{~cm}$ diameter). These cobbles were broken with a rock hammer, and weathering rinds were measured to the 
nearest $0.5 \mathrm{~mm}$ (Birkeland, 1973). The percent cover was visually estimated for each plot. I recorded percent bare ground, vegetated ground cover, and tree cover (Stork, 1963).

\section{Particle Size and Orientation Measurements}

I used variable size plots $(3 \mathrm{~m} \mathrm{x} \mathrm{3-15} \mathrm{m})$ to measure boulder $(\geq 30 \mathrm{~cm})$ frequency and size distributions within each plot including at least 30 boulders. For each plot, two points were laid out along the crest of the feature three meters apart. I recorded boulder dimensions progressing down the slope of the feature until at least 30 boulders were measured. I mapped each plot and recorded its slope and orientation.

I measured the three primary axes, A/B/C, of each boulder (Krumbein, 1941) where the A axis represents the longest axis of the particle, the B axis is the second longest axis, and the $\mathrm{C}$ axis is the width of the particle represented by a line oriented perpendicular to the A axis. I recorded the long axis orientation of each boulder with a Brunton compass to determine particle orientation (Caine, 1967). Where the $\mathrm{A}$ axis was nearly perpendicular to the slope, no orientation was recorded, but the stone was included in the frequency count.

\section{Transect Sampling}

I recorded boulder frequency, size, orientation, and age using a $330 \mathrm{~m}$ transect parallel to the moraine's slope and continuing across the cirque floor. The transect (Figure 5, dotted line) began mid-way between the crest and the base of the moraine 
where the slope value was similar to that of the surrounding talus slopes $\left(25^{\circ}\right)$ and continued across the cirque floor to the creek that marks the northeastern boundary of the cirque. Along this line I sampled lichens and boulders using the point-center quarter method (Cottam and Curtis, 1956). This method is suitable for large areas where the objects to be measured are widely spaced and can be used to calculate densities and frequencies of species. I established sample points along the transect every $10 \mathrm{~m}$ where I divided the area into quadrants. Within each quadrant, I measured the distance to the nearest $R$. geographicum lichen and noted its diameter. In addition, I measured the three principal axes and orientation of the long axis for the boulder that served as the lichen's substrate. If no lichen was found within a $5 \mathrm{~m}$ arc from the center point into the quadrant (the distance where adjacent points overlapped), only boulder measurements for the nearest stone were recorded.

\section{Soil sampling}

Soil development and particle size percentages were derived from six soil profiles located in each of the four plots on the rock islands, one in the swale between two of the rock islands, and one on the moraine (Figure 5, Plots 5-9 and 10). I gathered surface sediment samples from the moraine and the debris that mantles the glacier for comparison (Figure 5, Plots 10 and 11).

Soils were described for each of these locations following U.S. Department of Agriculture Soil Taxonomy (Soil Survey Staff, 1999) with modifications to horizon nomenclature suggested by Birkeland (1999). Colors are based on the Munsell Soil 
Color Chart (Munsell Color Company, 1954). I described soils on the shoulder position of the features based on recommendations by Haugland (1998) that these areas should have the greatest degree of soil development.

\section{LABORATORY ANALYSIS}

Particle size was determined throughout each soil profile using the pipette method (Galehouse, 1971). I measured soil acidity ( $\mathrm{pH}$ ) using the 1:1 distilled water method (USDA, 1972). In a few instances, more water was needed to create a paste, and the ratio was increased to $2: 1$, distilled water to soil. In general, soil $\mathrm{pH}$ will decrease over time as carbonic acid input from vegetation and leaching from atmospheric rainwater weathers primary minerals and translocates ions down through the soil profile (Birkeland, 1999). Although pH usually reaches a steady state in a soil long before other diagnostic features, it can be useful for differentiating relatively young soils (Tonkin and Basher, 1990).

In wet environments, volcanic glass weathers quickly to the clays allophane, imogolite, opaline silica, and ferrihydrite; however, it is difficult to detect these materials using particle size analysis as they are difficult to disperse (Birkeland, 1999). If combined with high organic carbon content, these allophonic materials form a very porous structure with a resulting low soil bulk density. Low bulk density is an important diagnostic indicator of andisols (volcanic soils) (Soil Survey Staff, 1999) but is difficult to assess with skeletal soils (Vincent and Chadwick, 1994). The 
presence of amorphous clay, then, is often indicative of volcanic parent material and soils with andic properties.

I measured the sodium fluoride $(\mathrm{NaF}) \mathrm{pH}$ in the soils with cambic horizons to detect the presence of amorphous material (Soil Survey Staff, 1999). In the test, the flourine replaces the $\mathrm{OH}$ of the amorphous material; if the $\mathrm{pH}$ registers higher than 9.4 after two minutes in a solution of one gram soil / $50 \mathrm{ml} 1 \mathrm{M} \mathrm{NaF}$, there is a dominance of amorphous material (Fieldes and Perrott, 1966). Values exceeding $9.4 \mathrm{NaF} \mathrm{pH}$ in a mineral horizon serve as a surrogate for bulk density measurements in this study and allow for the proper classification of soils with andic soil properties (Soil Survey Staff, 1999).

Total organic matter was measured using the loss on combustion method (Allison, 1965). Soil weights were taken before and after 4 hours combustion at $550^{\circ} \mathrm{C}$. The percent difference represents the total organic matter for each horizon. Classification of andic properties requires determination of the amount of water a soil can retain-its vitric property. If under $1500 \mathrm{kPa}$ the change in weight from an air-dried sample is less than 15\%, the soil is vitrandic (Soil Survey Staff, 1999). I assessed this quality by oven drying air-dried samples of the $\mathrm{B}$ horizons for 12 hours at $105^{\circ} \mathrm{C}$. The difference in weight indicates the moisture lost and provides a percentage of water retention. Soil development is compared based on particle fine-fraction distribution, clay accumulation, and Harden's (1982) profile development index (PDI). 


\section{STATISTICAL AND GRAPHICAL ANALYSIS}

The data from the eight plots, transect, and soils were plotted and, where appropriate, analyzed for normality using histograms and the Kolmogorov-Smimoff test (Sokol and Rohlf, 1995). Much of the data are spatial and not normally distributed; as such, all data are analyzed using non-parametric statistics. I assessed the boulder frequency, abrasion ratio, and percent of bare ground, ground cover, and tree cover for each plot. In addition, I compared the maximum lichen thalli diameter for R. geographicum, the five largest lichens (Innes, 1984), and weathering rind thickness in each plot.

I compared boulder axes lengths between plots using the Kruskal-Wallis test (Sokol and Rohlf, 1995) and, where significant differences occurred, I used the MannWhitney U-test (Sokol and Rohlf, 1995) to determine which sample plots were different from the others. Comparing the A axis orientation data is more problematic. Orientation datum is normally recorded as an azimuth; it has a circular rather than a linear distribution. I used Curray's (1956) method for comparing samples using twodimensional orientation data. This method provides a measure of central tendency or preferred orientation that is independent of origin. This resultant vector is assessed for significance using Rayleigh's L\% (1894).

I used Spearman's rank coefficient (Sokol and Rohlf, 1995) to compare the size and shape of boulders along the transect. Changes in clast shape were assessed by comparing sphericity $\left(C^{2} /[A \times B]\right)^{333}$, elongation $(A / B)$, and flatness $[(A+B) / 2 C]$ where A, B, and C represent the boulder's principal axes (Goudie, 1990; Perez, 2000). 
I divided the transect into three distinct units based on slope for subsequent analysis. The upper section runs from the beginning of the transect on the moraine to the moraine base where the slope becomes similar to that of the rock islands. The middle section spans from the base of the moraine to a point where the transect changes direction; at this point, the downslope direction shifts from an azimuth of $30^{\circ}$ to an azimuth of $0^{\circ}$. The lower section continues to the boundary of the cirque at Thielsen Creek. I used the Kruskal-Wallis and Mann-Whitney U-test to assess any significant differences between these sections regarding A or B axes length, sphericity, elongation, or flatness. I also compared the maximum lichen diameter and mean diameter of the five largest lichens between sections. Finally, I calculated a resultant vector for each section and checked these values for significant orientation. Together, these methods allowed me to describe the Neoglacial history for Mt. Thielsen, assess the utility of these relative dating methods, and compare my results with other studies in the western cordillera. 


\section{CHAPTER V}

\section{RESULTS}

Three features were identified and preliminarily classified in the north cirque of Mt. Thielsen (Figure 6). Immediately in front of the Lathrop Glacier at an elevation of $2410 \mathrm{~m}$ is a moraine at least $2 \mathrm{~m}$ in height (measured on its proximal side) and 13.9 $\mathrm{m}$ wide (measured at eye level) with a steep distal slope angle $\left(36^{\circ}\right)$ facing $\mathrm{N} 28^{\circ} \mathrm{E}$ (Figure 6). Adjacent to the moraine at an elevation of $2390 \mathrm{~m}$ is a $5 \mathrm{~m}$ high $3.1 \mathrm{~m}$ wide protalus rampart with a distal slope angle of $28^{\circ}$ and an orientation of $\mathrm{N} 30^{\circ} \mathrm{E}$. Below these features at an elevation of $2130-2225 \mathrm{~m}$ are four rock islands, deposits from rockfall. The rock islands are long narrow features up to $3 \mathrm{~m}$ high and $33 \mathrm{~m}$ wide with their long axis oriented roughly with the downslope direction.

\section{WEATHERING CHARACTERISTICS AND LICHENOMETRY}

The moraine, proximal side of the rampart, and rock island 5 (plot 5) have relatively high boulder frequencies ranging from $489 / 100 \mathrm{~m}^{2}$ on the proximal side of the moraine to $199 / 100 \mathrm{~m}^{2}$ on rock island 5 . Boulder frequency on the distal side of the rampart is $103 / 100 \mathrm{~m}^{2}$ and $<100 / 100 \mathrm{~m}^{2}$ on rock islands 6,7 , and 8 (TABLE II). Boulder frequency is higher on the proximal sides of the moraine and rampart than on the distal sides. 


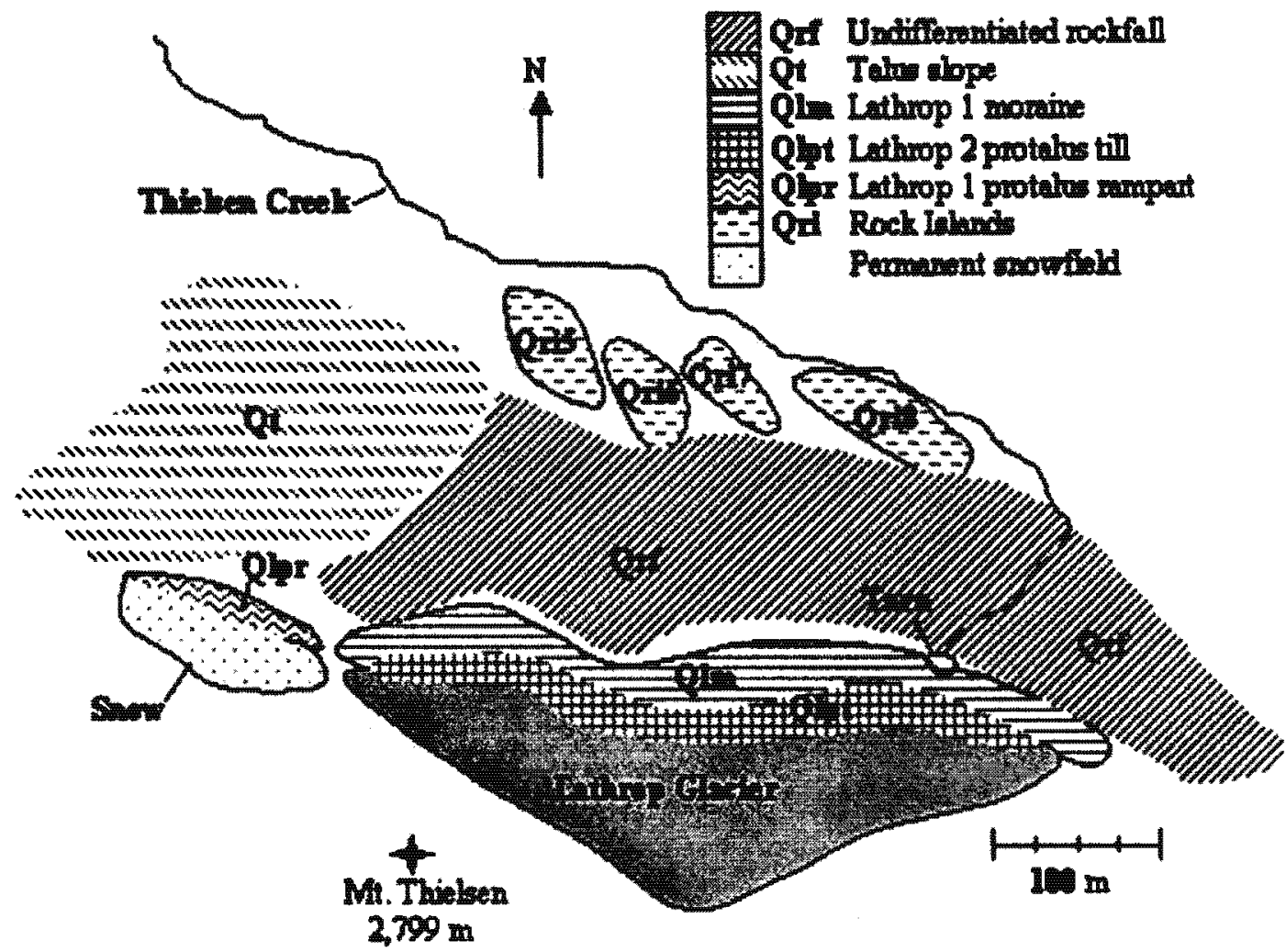

Figure 6. Map of glacial and periglacial features on Mt. Thielsen.

Abrasion ratios are $100 \%$ fresh stones for the moraine, rampart, and rock island 5. There are a few weathered stones on the remaining rock islands, and abrasion ratios range from $94-98 \%$ fresh stones. There is no vegetation on the proximal sides of the moraine and rampart and $<1 \%$ total vegetation cover on the distal sides. Rock island 5 has $10 \%$ vegetation cover consisting of vegetation ground cover and two small trees ( $T$. mertensiana) located at the north edge of the sampling plot. The remaining rock islands are similar in appearance with ground cover and dense stands $T$. mertensiana accounting for $25 \%$ vegetation cover. 
No lichens were found on the moraine or rampart. However, each of the rock islands had boulders with at least $10 \%$ lichen coverage. Maximum R. geographicum diameters on the rock islands range from $40-55 \mathrm{~mm}$. The largest lichen was found on rock island 6. However, the highest mean $(35.4 \mathrm{~mm})$ of the five largest lichens occurred on rock island 8 . Rock island 7 is the only feature where lichenometry suggests an age younger than the other rock islands (maximum diameter $40 \mathrm{~mm}$; mean for 5 largest lichen $30.2 \mathrm{~mm}$ ).

\section{BOULDER SIZE AND ORIENTATION}

Large angular stones are ubiquitous on all features in the cirque. Median values for boulder $\mathrm{A}$ axes and $\mathrm{B}$ axes lengths were similar among the features with the exception of rock island 7 (TABLE II). Boulder lengths on the moraine and rampart were smaller than those on the rock islands with rock island 5 having intermediate values (Figure 7). Boulders on rock island 7 are significantly larger $(p<.05)$ than on any other feature except rock island 6, which has the greatest range of boulder sizes, 30$277 \mathrm{~cm}$ (TABLE III). Boulders on the rampart are significantly smaller than on most other features $(p<.05)$, although there is no difference between the two sides of the rampart. 
TABLE II

WEATHERING CHARACTERISTICS AND LICHENOMETRY FOR FEATURES IN THE NORTH CIRQUE OF MT. THIELSEN.

\begin{tabular}{|c|c|c|c|c|c|c|c|c|}
\hline Feature & Plot \# & $\begin{array}{c}\text { Stone frequency } \\
\text { (stones }>0.3 \mathrm{~m} \\
\text { diameter } / 100 \\
\mathrm{~m} 2 \text { ) }\end{array}$ & $\begin{array}{l}\text { Abrasion ratio } \\
\text { (\% fresh to } \\
\text { weathered } \\
\text { stones) }\end{array}$ & $\begin{array}{l}\text { Vegetation } \\
\text { cover }(\%)\end{array}$ & $\begin{array}{l}\text { Maximum } \\
\text { weathering } \\
\text { rind } \\
\text { thickness } \\
\text { (mm) }\end{array}$ & $\begin{array}{l}\text { Maximum } \\
\text { lichen } \\
\text { diameter } \\
(\mathrm{mm})\end{array}$ & $\begin{array}{l}\text { Mean } 5 \text { largest } \\
\text { lichens (mm) }\end{array}$ & $\begin{array}{c}\text { Lichen } \\
\text { cover }(\%)\end{array}$ \\
\hline
\end{tabular}

\begin{tabular}{|c|c|c|c|c|c|c|c|c|}
\hline $\begin{array}{l}\text { Moraine, } \\
\text { Proximal }\end{array}$ & 1 & 489 & 100 & 0 & 0 & $\sim$ & $\sim$ & 0 \\
\hline $\begin{array}{l}\text { Moraine, } \\
\text { Distal }\end{array}$ & 2 & 123 & 100 & $<1$ & 0 & $\sim$ & $\sim$ & 0 \\
\hline $\begin{array}{l}\text { Rampart, } \\
\text { Proximal }\end{array}$ & 3 & 220 & 100 & 0 & 0 & $\sim$ & $\sim$ & 0 \\
\hline $\begin{array}{c}\text { Rampart, } \\
\text { Distal }\end{array}$ & 4 & 103 & 100 & $<1$ & 0 & $\sim$ & $\sim$ & 0 \\
\hline Rock Island & 5 & 199 & 100 & 10 & $<1$ & 40 & 33.4 & $0-10$ \\
\hline Rock Island & 6 & 94 & 98 & 25 & $<2$ & 55 & 33 & $0-25$ \\
\hline Rock Island & 7 & 87 & 96 & 25 & 3 & 40 & 30.2 & $0-25$ \\
\hline Rock Island & 8 & 69 & 94 & 25 & 4 & 49 & 35.4 & $0-10$ \\
\hline
\end{tabular}

$\sim$ No lichens found in these plots 


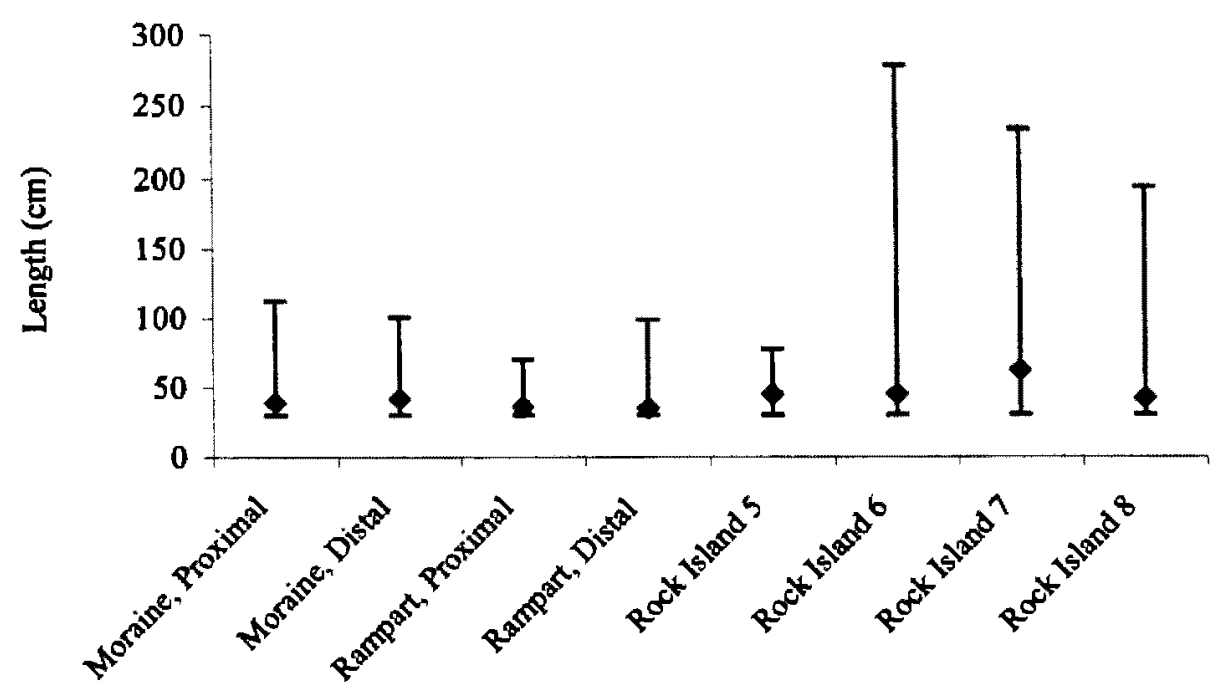

Figure 7. Median and range of values for $\mathrm{A}$ axis boulder lengths of talus features $1-8$. See Figure 5 for plot locations.

The distal side of the moraine has a slope angle of $36^{\circ}$ within $10 \mathrm{~m}$ of the crest. This value is near or exceeds the angle of repose and exceeds the other slope values in the cirque (TABLE III). The slope on the proximal side of the moraine is $2^{\circ}$. The proximal side of the rampart has a lower slope angle within $10 \mathrm{~m}$ of its crest $\left(25^{\circ}\right)$ than its distal side $\left(29^{\circ}\right)$. The latter value is similar to that of the adjacent talus slope $\left(28^{\circ}\right)$. The slope angles on the rock islands $\left(8-10^{\circ}\right)$ are representative of their toe-slope position in the cirque. 
TABLE III

BOULDER SIZES FOR FEATURES IN THE STUDY AREA

Feature Plot \# Slope A axis length (cm) B axis length (cm) (degrees) Median Range Median Range

\begin{tabular}{|c|c|c|c|c|c|c|}
\hline $\begin{array}{l}\text { Moraine, } \\
\text { Proximal }\end{array}$ & 1 & 2 & 39 & $30-113$ & 27 & $10-51$ \\
\hline $\begin{array}{c}\text { Moraine, } \\
\text { Distal }\end{array}$ & 2 & 36 & 42 & $30-101$ & 26.5 & $12-91$ \\
\hline $\begin{array}{l}\text { Rampart, } \\
\text { Proximal }\end{array}$ & 3 & 25 & $36 \dagger$ & $30-70$ & 23 & $11-54$ \\
\hline $\begin{array}{l}\text { Rampart, } \\
\text { Distal }\end{array}$ & 4 & 29 & $35 \dagger \dagger$ & $30-99$ & 21 & $10-83$ \\
\hline Rock Island & 5 & 9 & 45 & $30-78$ & 27 & $14-68$ \\
\hline Rock Island & 6 & 6 & 45 & $30-277$ & 25 & $8-151$ \\
\hline Rock Island & 7 & 10 & $62 \ddagger$ & $30-233$ & 39 & $10-167$ \\
\hline Rock Island & 8 & 8 & 42 & $30-193$ & 28 & $10-51$ \\
\hline
\end{tabular}

†Boulder A axis significantly smaller than plots $2,5,6,7,8$ at $p<.05$

$\dagger+$ Boulder $\mathrm{A}$ axis significantly smaller than plots $2,5,6,7$ at $\mathrm{p}<.05$

$\ddagger$ Boulder $\mathrm{A}$ axis significantly larger than plots $1,2,3,4,5,8$ at $\mathrm{p}<.05$

The resultant vector, a measure of central tendency independent of origin, showed a preferred downslope orientation for boulder $\mathrm{A}$ axes on each feature (Figure 8). However, the distal side of the rampart is the only feature with a significant vector orientation. The slope direction (azimuth plotted into the $0-180^{\circ}$ hemisphere) for this location is $34^{\circ}$ (TABLE IV). The resultant vector direction is $33^{\circ}$ with a significant vector magnitude (strength of orientation- L \%), of $35.5 \%$. A majority of boulders in rock islands 5,7 , and 8 are oriented near the resultant vector, but their variation is too 
great to record a statistically significant pattern. All other plots exhibit uniform or bimodal distributions and have low vector magnitudes.
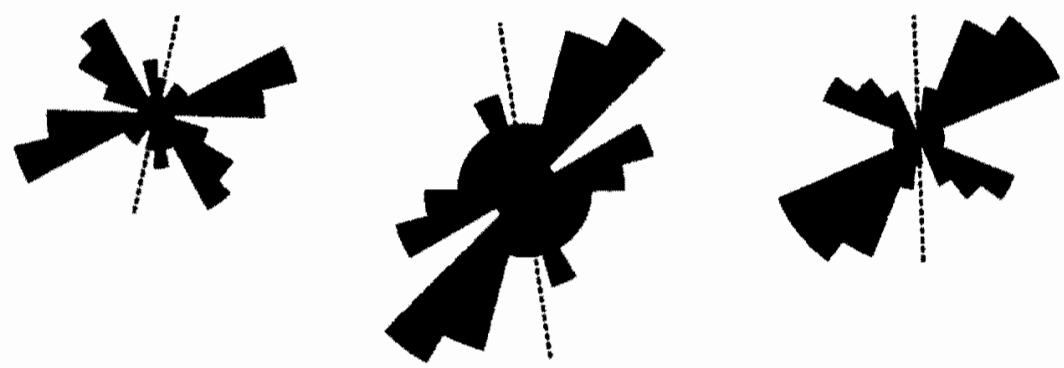

Moraine, Proximal

Moraine, Distal

Protalus rampart, Proximal

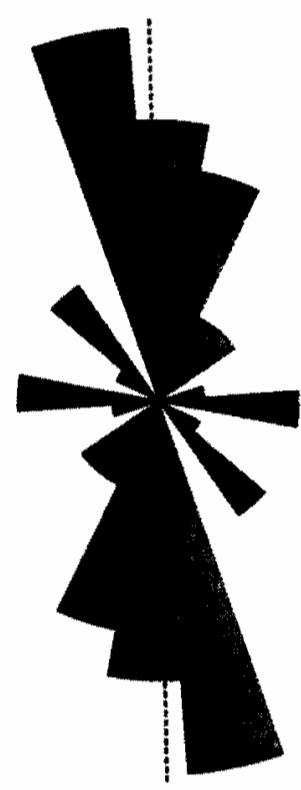

Protalus rampart, Distal
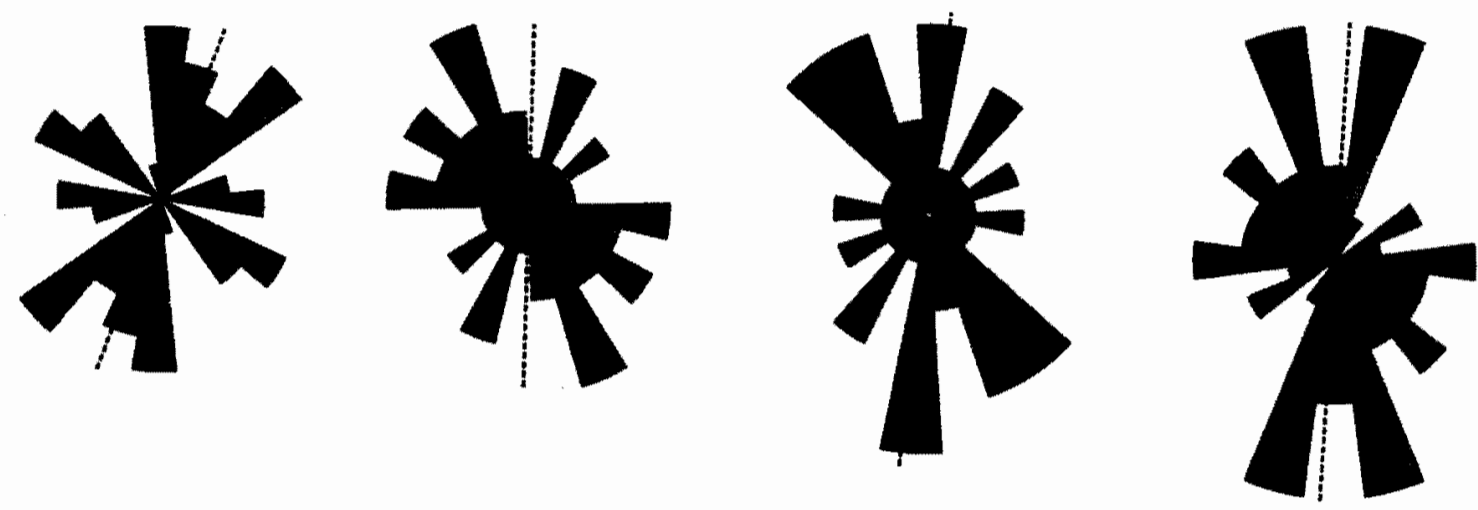

Rock island 5

Rock island 6

Rock island 7

Rock island 8

Figure 8. Rose diagrams of boulder orientations in plots grouped in $15^{\circ}$ sections. The tops of the diagrams represent the downslope direction. Dotted lines represent the resultant vector direction. 
TABLE IV

\section{BOULDER ORIENTATTONS FOR FEATURES \\ IN THE STUDY AREA}

\begin{tabular}{ccccc} 
Feature & Plot \# & $\begin{array}{c}\text { Slope } \\
\text { orientation }\end{array}$ & $\begin{array}{c}\text { Resultant vector } \\
\text { from A axes }\end{array}$ & $\begin{array}{c}\text { Vector magnitude } \\
\text { (L\%) }\end{array}$ \\
\hline $\begin{array}{c}\text { Moraine, } \\
\text { Proximal }\end{array}$ & 1 & 28 & 41 & 19.8 \\
Moraine, & & & & \\
Distal & 2 & 30 & 22 & 1.0 \\
Rampart, & & & & \\
Proximal & 3 & 23 & 21 & 8.3 \\
Rampart, & & & & \\
Distal & 4 & 34 & 33 & $35.5 *$ \\
Rock Island & 5 & 20 & 41 & 19.6 \\
Rock Island & 6 & 16 & 18 & 7.5 \\
Rock Island & 7 & 3 & 10 & 20.6 \\
Rock Island & 8 & 7 & 11 & 17.6 \\
\hline
\end{tabular}

* Significant vector orientation at $p<.05$

\section{TRANSECT DATA}

There is no significant relationship between distance along the transect and boulder size, boulder shape, and lichen size. Boulder sphericity and flatness are highly inversely correlated $\left(r_{s}=-.997, p<.01\right)$. There is no significant orientation of boulders for the entire transect. Boulder sizes differ among the upper, middle, and lower sections of the transect with median boulder sizes highest for the middle section ( $90.5 \mathrm{~cm}$ versus $70 \mathrm{~cm}$ and $68 \mathrm{~cm}$ for the upper and lower sections respectively) but are not statistically significant $(p=.622)$ (Figure 9). B axis lengths are also highest for the middle section but are not significant $(p=.517)$. 


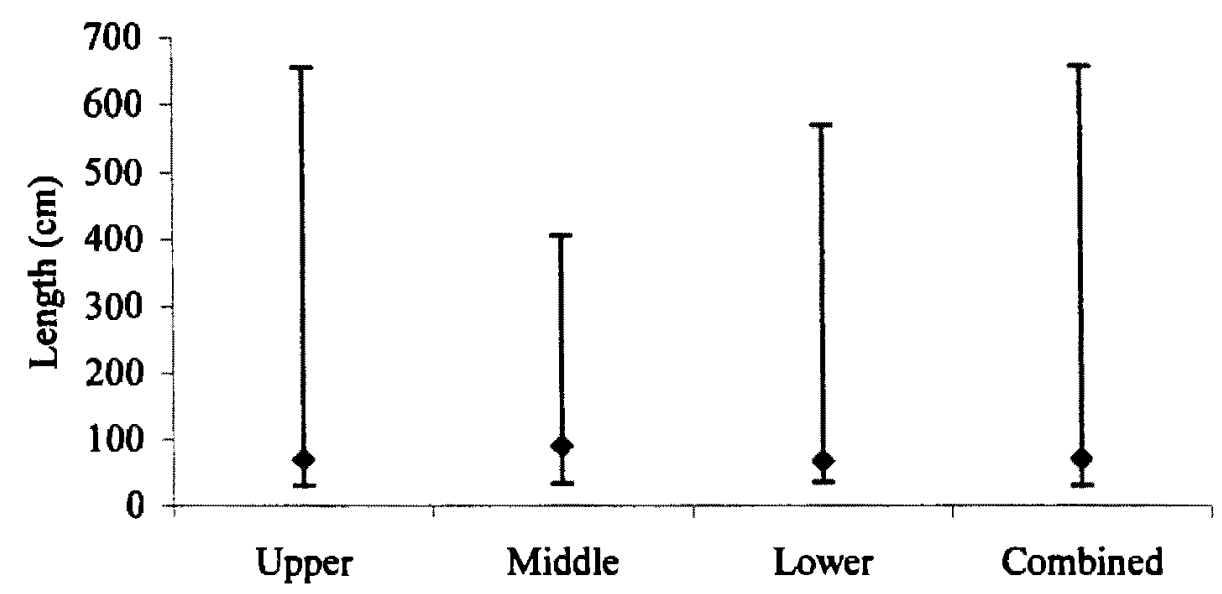

Figure 9. Median and range of values for $\mathrm{A}$ axis boulder lengths by section.

The maximum $R$. geographicum diameter, $46 \mathrm{~mm}$, is found in the lower section of the transect. This section also has the highest mean (32.4) for the five largest lichens (TABLE V). Slope values are greatest for the upper section and range from $23^{\circ}$ on the lower portion of the moraine to $12^{\circ}$ at the moraine base (TABLE V). The remainder of the transect is located on the cirque floor with slope values of $8^{\circ}$ $12^{\circ}$. Boulders in the lower section are significantly less spherical $(p<.05)$ and more flat $(p<.05)$ than boulders in the upper and middle sections (TABLE VI). There is no significant difference in the elongation index among the three sections.

Resultant vectors along the transect are aligned with the downslope direction within each section (Figure 10). However, only the lower section has a significant $(p<.05)$ resultant vector (Table VII). The middle section has a relative majority of boulders oriented downslope, but the variation is large; the upper section has a uniform distribution. 


\section{TABLE V}

\section{BOULDER SIZES AND LICHENOMETRY FOR TRANSECT SECTIONS}

\begin{tabular}{ccccccccccc} 
Section & $\begin{array}{c}\text { Slope } \\
\text { range } \\
\text { (degrees) }\end{array}$ & $\begin{array}{c}\text { Section } \\
\text { length }(\mathrm{m})\end{array}$ & $\begin{array}{c}\text { Number } \\
\text { of } \\
\text { boulders }\end{array}$ & A axis length $(\mathrm{cm})$ & B axis length (cm) & $\begin{array}{c}\text { Maximum } \\
\text { lichen } \\
\text { diameter } \\
(\mathrm{mm})\end{array}$ & $\begin{array}{c}\text { Mean } 5 \\
\text { largest } \\
\text { lichens } \\
(\mathrm{mm})\end{array}$ \\
\hline Upper & $23-12$ & 110 & 43 & 70 & $30-654$ & 50 & $19-308$ & 35 & 27.7 \\
Middle & $10-9$ & 100 & 42 & 90.5 & $33-407$ & 67 & $17-240$ & 38 & 29.2 \\
Lower & $8-12$ & 114.5 & 35 & 68 & $35-570$ & 51 & $14-320$ & 46 & 32.4 \\
Combined & & 324.5 & 120 & 70.5 & $30-654$ & 54 & $14-320$ & 46 & 39.4 \\
\hline
\end{tabular}


TABLE VI

BOULDER SHAPE CHARACTERISTICS FOR TRANSECT SECTIONS

\begin{tabular}{ccccc} 
Section & $\begin{array}{c}\text { Slope } \\
\text { range }\end{array}$ & $\begin{array}{c}\text { Median } \\
\text { sphericity elongation } \\
\text { index }\end{array}$ & $\begin{array}{c}\text { Median } \\
\text { index }\end{array}$ & $\begin{array}{c}\text { Median } \\
\text { flatness } \\
\text { ratio }\end{array}$ \\
\hline Upper & $23-12$ & 0.69 & 1.49 & 1.76 \\
Middle & $10-9$ & 0.74 & 1.37 & 1.64 \\
Lower & $8-12$ & $0.62^{*}$ & 1.43 & $2.12^{*}$ \\
Combined & & 0.69 & 1.4 & 1.8 \\
\hline
\end{tabular}

*Significant at $\mathrm{p}<.05$
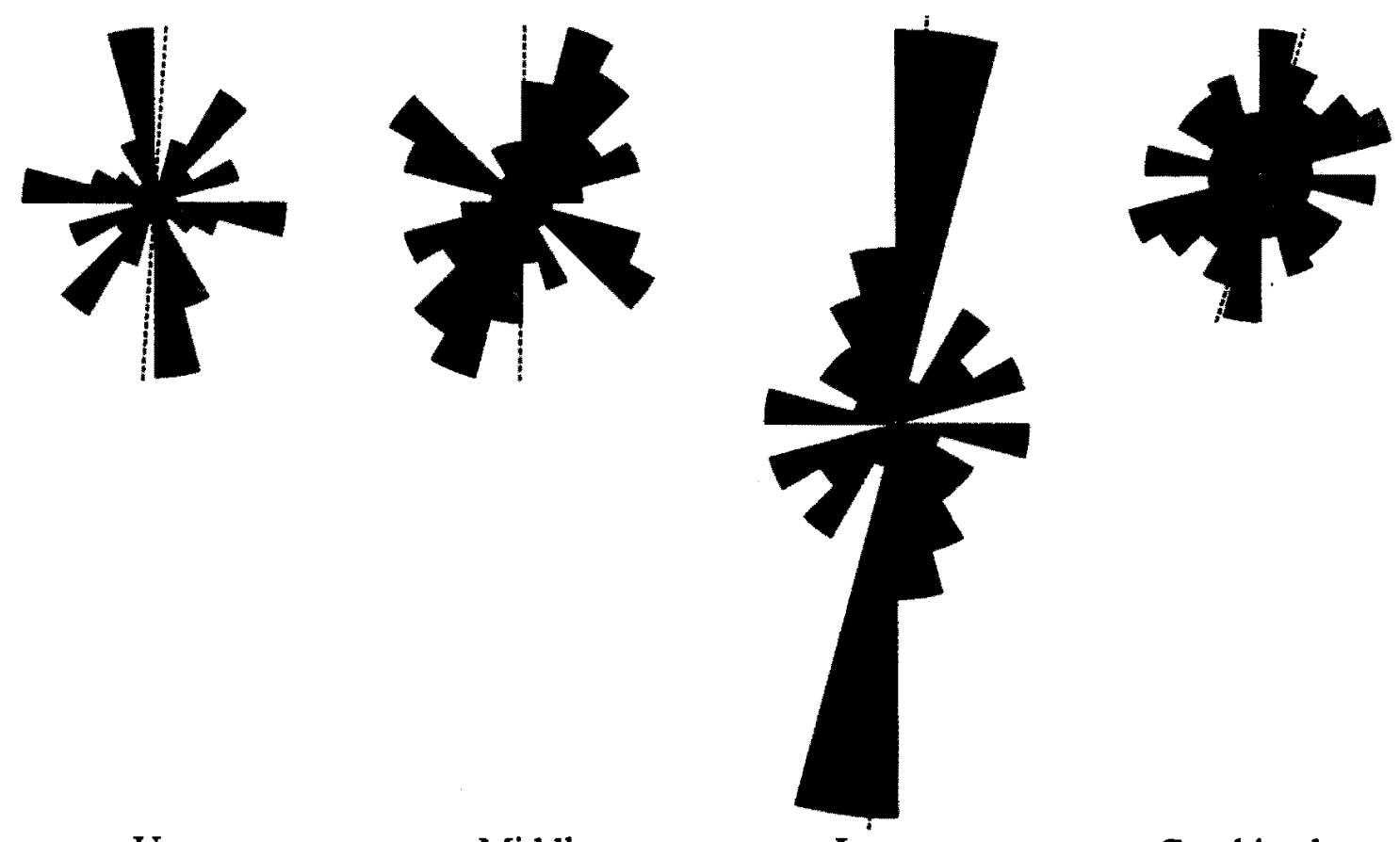

Upper

Middle

Lower

Combined

Figure 10. Rose diagrams of boulder orientations in transect grouped in $15^{\circ}$ sections. All diagrams are rotated such that the top of the diagram represents the downslope direction. Dotted lines represent the resultant vector direction. 
TABLE VII

BOULDER ORIENTATIONS FOR TRANSECT SECTIONS

\begin{tabular}{cccc} 
Section & $\begin{array}{c}\text { Slope } \\
\text { orientation }\end{array}$ & $\begin{array}{c}\text { Resultant } \\
\text { vector } \\
\text { from A } \\
\text { axes }\end{array}$ & $\begin{array}{c}\text { Vector } \\
\text { magnitude } \\
(\mathrm{L} \%)\end{array}$ \\
\hline Upper & $\mathrm{N} 30^{\circ} \mathrm{E}$ & 34 & 6.7 \\
Middle & $\mathrm{N} 30^{\circ} \mathrm{E}$ & 31 & 8.4 \\
Lower & $\mathrm{N} 0^{\circ}$ & 4 & $33.0^{*}$ \\
Combined & & 17 & 7.0 \\
\hline *Significant vector orientation at $\mathrm{p}<.05$
\end{tabular}

\section{SOILS}

There is only slight weathering of the surface material (Cox) of the moraine, and it is only slightly more weathered than a sample taken from the debris covering the glacier (TABLE VIII). Both the moraine and glacier samples have trace amounts of organic matter and a slightly acidic $\mathrm{pH}$ (6.6 and 6.7 respectively).

Soils on and near the rock islands are more strongly developed. Soils on rock islands 5,6 , and 8 have $\mathrm{A} / \mathrm{Bw} 1 / \mathrm{Bw} 2 /$ Cox profiles (Figure 11) with a depth of weathering exceeding $110 \mathrm{~cm}$ (TABLE VIII). Depths to the respective horizon boundaries are similar. Clasts are slightly weathered at depth and occur in a matrix of fines. The percentage of organic matter is generally highest in the A horizons and decreases with depth. The $\mathrm{pH}$ values tend to increase with depth and are moderately to slightly acidic (5.0-6.7). The maximum PDI values in B horizons for rock islands 6 and 8 are similar (3.62 and 3.64). A value of 2.18 PDI for the rock island 5 B horizon indicates this soil is slightly less developed. 
TABLE VIII

WEATHERING CHARACTERISTICS AND SOIL DEVELOPMENT INDICES FOR SOILS IN THE CIRQUE

\begin{tabular}{|c|c|c|c|c|c|c|}
\hline Site & Horizon & Depth (cm) & Dry Color & $\mathrm{pH}$ & $\begin{array}{c}\% \text { Organic } \\
\text { Matter }\end{array}$ & PDI \\
\hline \multirow[t]{4}{*}{ Rock Island 5} & A & $0-15$ & 10YR $3 / 3$ & 5.0 & 2.35 & 0.54 \\
\hline & Bwl & $15-47$ & 10YR 4/4 & 5.3 & 2.44 & 2.18 \\
\hline & Bw2 & $47-69$ & 10YR $5 / 4$ & 5.1 & 1.97 & 2.10 \\
\hline & Cox & $69-110+$ & $2.5 Y 6 / 4$ & 5.2 & 0.96 & 0.72 \\
\hline \multirow[t]{4}{*}{ Rock Island 6} & A & $0-15$ & $10 Y R 4 / 2$ & 5.0 & 2.44 & 0.54 \\
\hline & Bwl & $15-53$ & 10YR $5 / 4$ & 5.9 & 1.90 & 3.62 \\
\hline & $\mathrm{Bw} 2$ & $53-77$ & 10YR $6 / 6$ & 6.4 & 1.08 & 2.50 \\
\hline & $\operatorname{Cox}$ & $77-110+$ & $2.5 \mathrm{Y} 7 / 4$ & 6.3 & 0.98 & 0.29 \\
\hline \multirow[t]{6}{*}{ Rock Island 7} & $\mathrm{~A}$ & $0-11$ & 10YR $4 / 3$ & 6.2 & 2.18 & 0.40 \\
\hline & Bw1 & $11-39$ & 10YR 4/4 & 5.4 & 1.31 & 2.67 \\
\hline & Bw2 & $39-51$ & $10 Y R 3 / 4$ & 5.2 & 0.96 & 1.14 \\
\hline & $\mathrm{C}$ & $51-72$ & $2.5 \mathrm{Y} 4 / 2$ & 5.5 & 0.70 & 0.00 \\
\hline & $\mathrm{Ab}$ & $72-91$ & $10 \mathrm{YR} 4 / 2$ & 6.0 & 1.15 & 1.81 \\
\hline & Coxb & $91-110+$ & $10 \mathrm{YR} 3 / 2$ & 5.6 & 0.86 & 0.33 \\
\hline \multirow[t]{4}{*}{ Rock Island 8} & A & $0-16$ & $10 Y R 5 / 3$ & 5.4 & 1.44 & 0.58 \\
\hline & Bwl & $16-41$ & $10 Y R 5 / 5$ & 6.7 & 1.50 & 3.04 \\
\hline & Bw2 & $41-76$ & $10 \mathrm{YR} 6 / 5$ & 6.3 & 1.47 & 3.64 \\
\hline & Cox & $76-116+$ & $2.5 Y 6 / 3$ & 6.0 & 0.87 & 0.74 \\
\hline \multirow[t]{3}{*}{ Inter-Island } & A & $0-6$ & 10 YR $5 / 3$ & 5.9 & 2.35 & 0.11 \\
\hline & Bwl & $6-30$ & 10YR 5/4 & 6.1 & 2.62 & 2.29 \\
\hline & Bw2 & $30-72$ & $10 \mathrm{YR} 4 / 4$ & 5.7 & 1.46 & 2.10 \\
\hline Moraine & $\operatorname{Cox}$ & $0-10+$ & $10 \mathrm{Y} 2 / 1$ & 6.6 & trace & 0.00 \\
\hline Debris on Glacier & $\mathrm{C}$ & $0-10+$ & $10 Y 4 / 1$ & 6.7 & trace & 0.00 \\
\hline
\end{tabular}

The inter-island soil, sampled between rock islands 7 and 8, has a similar profile dimension and depth but no Cox horizon was reached. Organic matter percentages and $\mathrm{pH}$ are also similar. Soil development is intermediate between rock islands 6,8, and 5 based on a B horizon PDI of 2.29. 
Rock island 7 has a distinctive soil profile (Figure 12). The $\mathrm{C}$ horizon at a depth of 51-72 cm consists of slightly weathered angular clasts with interspersed fines. Below this layer is a relatively darker horizon with a higher organic matter percentage; this is considered to be a buried A horizon. The resulting profile is $\mathrm{A} / \mathrm{Bw} 1 / \mathrm{Bw} 2 / \mathrm{C} / \mathrm{Ab} / \mathrm{Coxb}$. The $\mathrm{pH}$ varies throughout this profile. The PDI for the prominent B horizon, 2.67 , is within the range of the other rock islands. The buried soil has a lower PDI value of 1.81 .

Particle size distribution is similar for all soils. Clay development is low and never exceeds $2.9 \%$ by weight for any horizon (TABLE IX). All horizons are loamy sand or sand with skeletal single grain structure. Moist consistence is loose, and all horizons are non-sticky and non-plastic to slightly plastic. Gravel percentages are lowest for the inter-island soil (10.8-30.3\%) and increase for soils on rock islands 6 and $8(17.2-36.5 \%)$. Gravel percentage increases in the weaker developed rock island 5 and 7 soils. The anomalous $\mathrm{C}$ horizon on rock island 7 has a gravel percentage of $50.1 \%$, the highest value for any horizon other than the moraine at $59.0 \%$. The Cox silt percentages are relatively high for the two best developed soils, rock island 6 $(22.4 \%)$ and rock island $8(28.6 \%)$, probably due to translocation of silts over time.

The mineral horizons for all soils lost $<15 \%$ of their air-dried weight after oven drying; the range of loss was $2-6 \%$. The $\mathrm{NaF}$ pH ranged from $10.6-11.7$ in the cambic horizons. The moraine soil is a weakly developed Entisol classified as a Vitrandic Cryorthent. The rock island and inter-island soils are moderately developed Andisols, Typic Vitracyrands. 


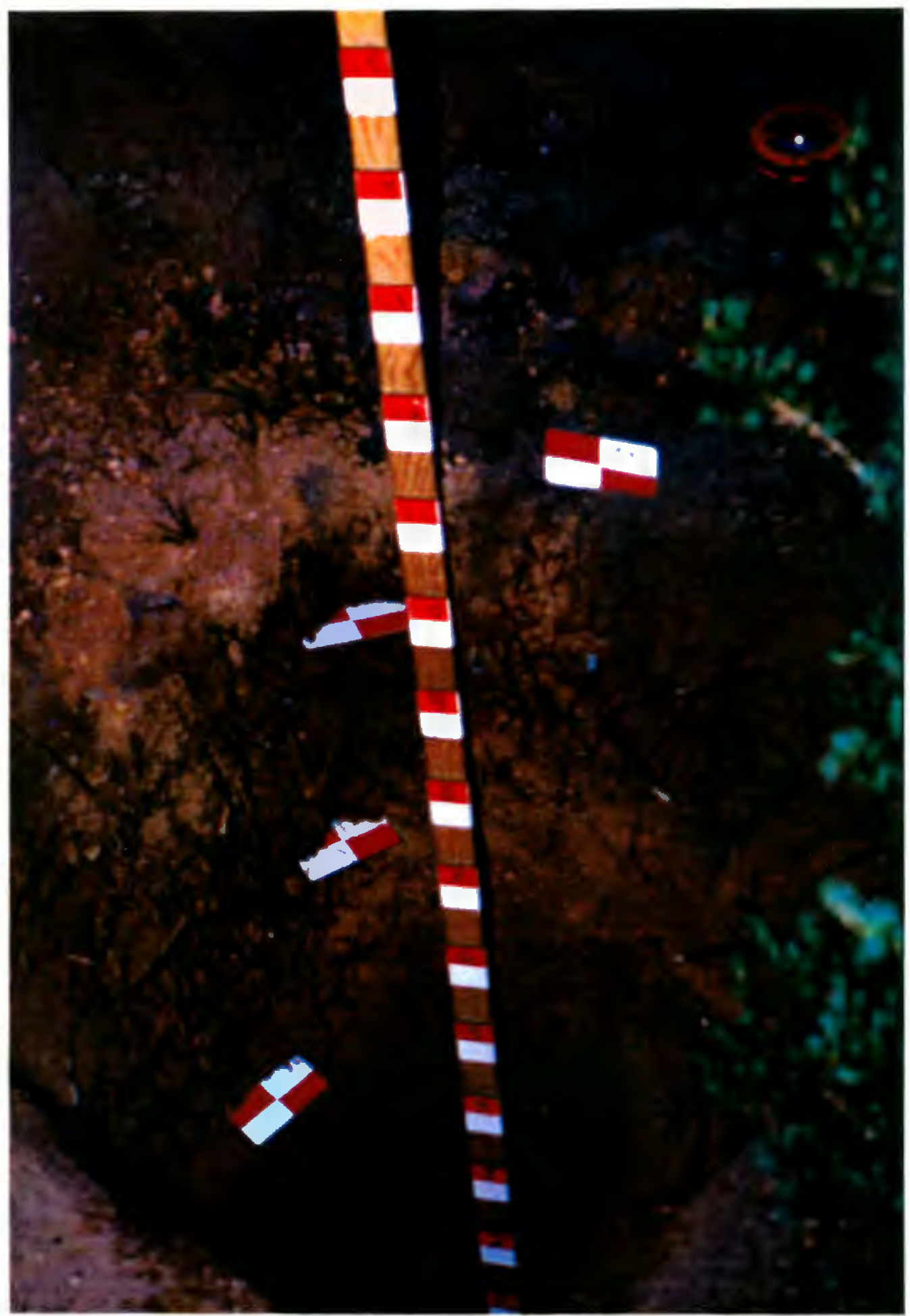

Figure 11. Soil profile for rock island 8. Note the lack of angular clasts and abundance of ash. 


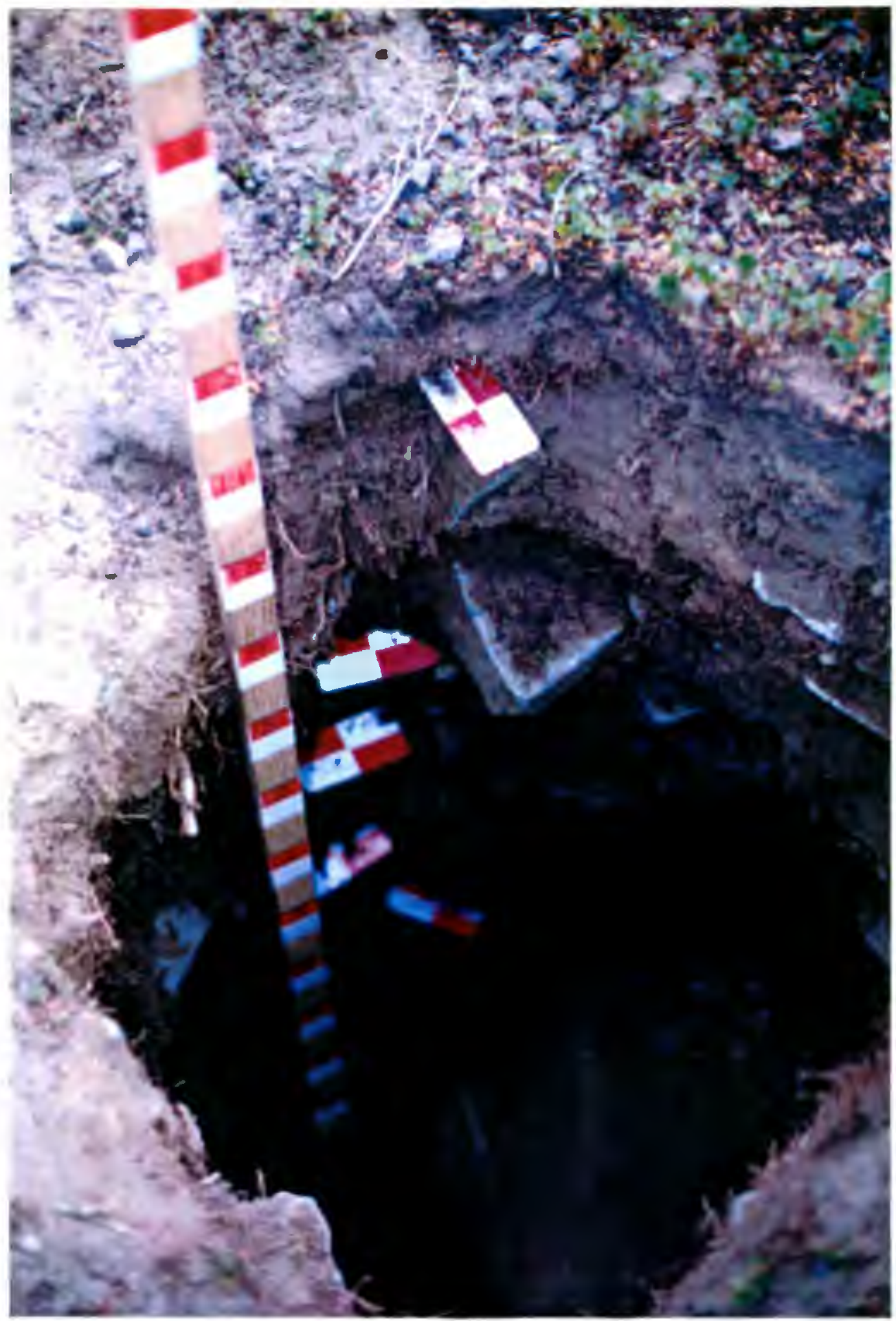

Figure 12. Soil profile for rock island 7. Note the clustering of angular clasts beginning at a depth of $50 \mathrm{~cm}$. 
TABLE DX

\section{PARTICLE SIZE DATA FOR SOILS IN THE STUDY AREA}

\begin{tabular}{|c|c|c|c|c|c|c|c|}
\hline Site & Horizon & $\begin{array}{l}\text { Depth } \\
\text { (cm) }\end{array}$ & Texture & Sand \% & Silt \% & Clay \% & $\begin{array}{c}>2 \mathrm{~mm} \\
\%\end{array}$ \\
\hline \multirow[t]{4}{*}{ Rock Island 5} & A & $0-15$ & Loamy sand & 79.4 & 19.5 & 0.9 & 36.8 \\
\hline & Bw1 & $15-47$ & Loamy sand & 77.4 & 21.1 & 1.4 & 44.1 \\
\hline & Bw2 & $47-69$ & Loamy sand & 80.5 & 17.8 & 1.7 & 43.8 \\
\hline & Cox & $69-110+$ & Loamy sand & 79.5 & 18.8 & 1.3 & 36.7 \\
\hline \multirow[t]{4}{*}{ Rock Island 6} & A & $0-15$ & Sand & 85.4 & 13.4 & 0.9 & 17.2 \\
\hline & Bw1 & $15-53$ & Loamy sand & 80.5 & 17.6 & 1.3 & 33.3 \\
\hline & Bw2 & $53-77$ & Loamy sand & 80.8 & 17.3 & 1.9 & 36.5 \\
\hline & Cox & $77-110+$ & Loamy sand & 76.1 & 22.4 & 1.0 & 23.5 \\
\hline \multirow[t]{6}{*}{ Rock Island 7} & A & $0-11$ & Loamy sand & 83.2 & 14.9 & 1.4 & 20.2 \\
\hline & Bw1 & $11-39$ & Loamy sand & 84.6 & 14.1 & 1.1 & 13.2 \\
\hline & Bw2 & $39-51$ & Loamy sand & 82.5 & 14.8 & 2.0 & 36.5 \\
\hline & $\mathrm{C}$ & $51-72$ & Loamy sand & 83.1 & 13.4 & 2.9 & 50.1 \\
\hline & $\mathrm{Bb}$ & $72-91$ & Sand & 88.2 & 9.1 & 2.3 & 47.3 \\
\hline & $\mathrm{Cb}$ & $91-110+$ & Sand & 88.2 & 9.1 & 2.3 & 44.1 \\
\hline \multirow[t]{4}{*}{ Rock Island 8} & $\mathrm{~A}$ & $0-16$ & Loamy sand & 82.5 & 16.4 & 0.9 & 24.5 \\
\hline & Bw1 & $16-41$ & Sand & 86.0 & 12.7 & 1.1 & 22.5 \\
\hline & Bw2 & $41-76$ & Sand & 87.8 & 10.7 & 1.3 & 33.9 \\
\hline & Cox & $76-116+$ & Loamy sand & 69.9 & 28.6 & 1.3 & 27.8 \\
\hline \multirow[t]{3}{*}{ Inter-Island } & A & $0-6$ & Sand & 86.5 & 11.5 & 1.8 & 12.2 \\
\hline & Bwl & $6-30$ & Sand & 86.4 & 11.3 & 1.9 & 10.8 \\
\hline & Bw2 & $30-72$ & Loamy sand & 83.0 & 14.6 & 1.9 & 30.3 \\
\hline $\begin{array}{l}\text { Moraine } \\
\text { Debris on }\end{array}$ & Cox & $0-10+$ & Sand & 91.5 & 6.6 & 1.9 & 59.0 \\
\hline Glacier & $\mathrm{C}$ & $0-10+$ & Loamy sand & 83.0 & 14.3 & 2.7 & 74.0 \\
\hline
\end{tabular}




\section{CHAPTER VI}

\section{DISCUSSION}

\section{FEATURE CLASSIFICATION}

Slope profiles, boulder frequency, size, and orientation allow for the classification of the moraine and talus features in the cirque. Similar diagnostic criteria have been used successfully to classify talus features in other alpine locations. However, as with other alpine areas, no single method can be directly applied to the features on Mt. Thielsen because of the dynamic and diverse processes affecting landform development. The moraine and talus-derived features on Mt. Thielsen are polygenetic in origin and exhibit complex formation processes.

\section{Distinctions Between Moraines and Protalus Ramparts}

Generally, moraine and talus-derived features can be distinguished by the form, size, frequency, and orientation of particles. Morainal material can vary from silt size to large boulders (Easterbrook, 1993), and particles are usually rounded from glacial transport. Some larger particles may ride along the top of the glacier, remain mostly angular, and be deposited on top of a moraine.

Because of the different transport processes, moraines are as likely to have large particles within the moraine as on top of it. Protalus ramparts normally lack fine material in any appreciable amount, since they form by rocks rolling along a snowfield 
and stacking up at the snow's base (Washburn, 1980). There may be a contribution of fines from eolian debris and slush avalanching, but it normally settles through the matrix of stacked angular boulders that constitute the rampart (Pérez, 1990). Thus, a heterogeneous mixture of unconsolidated sub-angular debris is usually indicative of a moraine while protalus ramparts normally consist of more homogenous sized angular boulders and have few fines.

Features formed by rockfall normally have a uniform distribution of boulder orientations as each stone is equally likely to come to rest with its long axis in one direction as another (Caine, 1967). Conversely, rocks sliding along a slope tend to develop a preferential down slope orientation (Perez, 2000). Rockfall also stratifies boulders by size; larger rocks tumble to the base of a talus deposit while smaller boulders accumulate near the apex (Rapp, 1960). In the case of protalus ramparts, larger boulders may bounce over the feature and continue down slope whereas, smaller stones may lack the energy to roll all the way to the feature (Shakesby et al,, 1987). Boulders on a moraine are neither stratified by size nor significantly oriented. Thus, talus slopes should show particle size sorting, small to large from apex to base, and stones should be preferentially oriented near the apex and uniformly distributed near the base. Protalus ramparts should have a small range of boulder sizes on both sides of the feature, relatively high boulder densities, and a uniform distribution of long axis orientations. By comparison, moraines should have a wide range of boulder sizes, relatively low boulder density, and also no significant orientation of particle long axis. 
The distal slope of the moraine is much steeper than talus slopes in the cirque, is similar to slope values reported for end moraines on other Cascade volcanoes (Scott, 1977, Scott and Gardner, 1990), and is beyond the angle of repose for andesite talus (Andrews, 1961). Boulder frequency is relatively low on the distal side, a reflection of the abundant fines typical of till (Dreimanis, 1989). The range of boulder sizes is high and several partially buried erratics over $3 \mathrm{~m}$ in length were observed. Boulders have angular shapes, and $\mathrm{A}$ axes show a uniform distribution. In sum, the qualities of the distal slope indicate a glacial origin for this feature.

The proximal side of the moraine is markedly different for nearly every diagnostic category. The slope is shallow and is more similar to proximal slopes on protalus ramparts (Ballantyne and Kirkbridge, 1986). Boulder frequency is highest on this proximal slope and is nearly four times greater than for the distal side of this feature. There is a lack of fines, and the boulders are angular with a uniform orientation. The data from the proximal slope of this feature suggest it is appropriately classified as a protalus rampart.

Morphometric and particle characteristics on the proximal side of the moraine are quite different from those on the distal slope indicating this feature is neither a classic end moraine nor a true protalus rampart. The polygenetic nature of this feature suggests it formed initially as an end moraine; material was transported both in and along the top of the glacier leaving till with abundant fines and erratics.

Simultaneously, and particularly after the glacier began to recede, the moraine acted as a barrier to rockfall debris. The shallow slope on the proximal side is a function of the 
area between the moraine and the glacier filling in with rockfall (Figure 13). The size of this material is similar to the material on the proximal side of the adjacent protalus rampart (Figure 14) suggesting a rampart formation process.

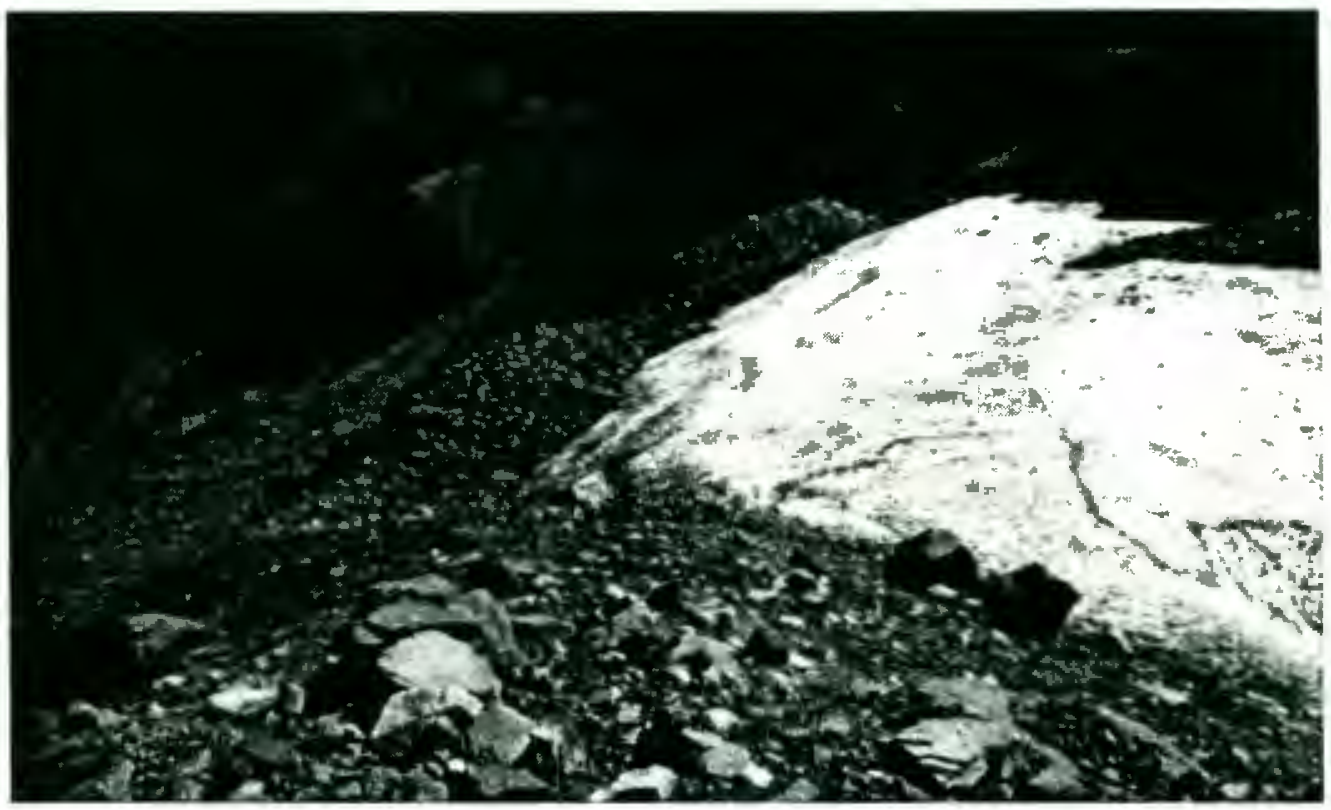

Figure 13. Moraine and glacier mantled with protalus till.

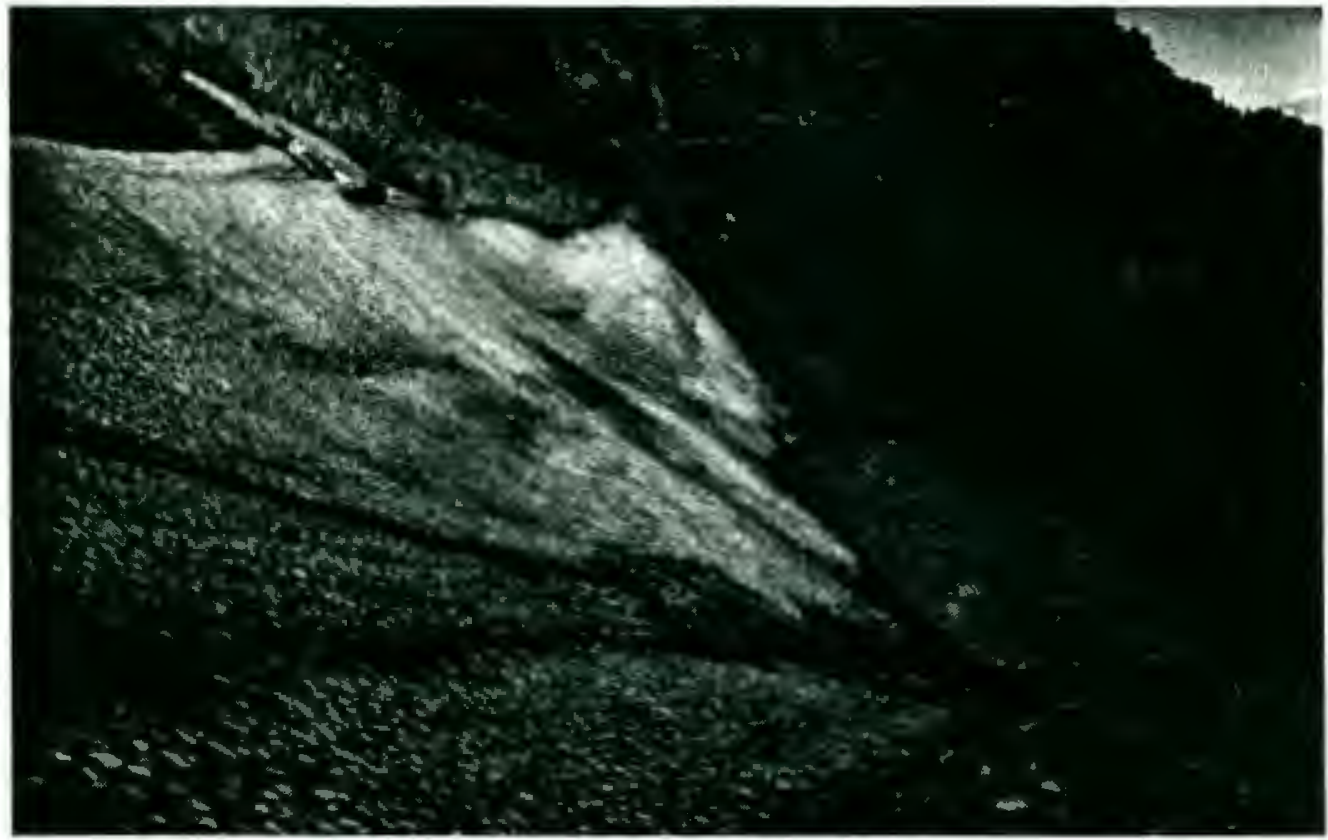

Figure 14. Protalus rampart adjacent to the moraine in figure 13. 
A polygenetic description for a moraine/rampart is not common in the literature. Most authors are specifically interested in classifying features as one or the other (Washburn, 1980; Ballantyne and Kirkbride, 1986; Shakesby, 1997). Warren (1989) suggests differentiating between material transported supra-glacially and material deposited by gravity. According to Warren (1989), the former is true till since it is carried by the glacier and deposited after ice melt. The latter Warren terms "protalus till" (1989, p. 145) because it bounces along the ice and accumulates at the ice margin much like the classic protalus rampart process. This phenomenon is probably more common during moraine formation than is typically reported.

Nonetheless, it is difficult to distinguish which particles are true till and which are protalus till when observing inactive features. Most end moraines are located on the cirque floor and far enough from the headwall that the continued contribution of rockfall after ice melt is probably not significant. The moraine/rampart feature on Mt. Thielsen is less than $200 \mathrm{~m}$ from the rock cliff and is positioned mid-way down the slope. Therefore, rockfall material can easily reach the feature and was observed doing so several times during field sampling.

The Lathrop Glacier is mostly covered by debris making it impossible to determine its extent. However, annual observations over the past 30 years indicate the moraine changes shape over time indicating movement of ice in contact with the moraine (Ralph Nafziger, personal communication). The moraine has several anatomizing ridges, and a distal slope that exceeds the angle of repose of the adjacent talus slopes. This is similar to a "push-deformation" moraine described by Shakesby 
et al., (1987, p. 309). Thus, the feature is classified as a polygenetic push-deformation moraine with contributions of protalus till.

Adjacent to this feature is a more typical protalus rampart. The distal slope of this feature is only slightly steeper than nearby talus slopes and is similar to distal slope angles for protalus ramparts at many other locations (Shakésby, 1997, Table 1). The high angularity of volcanic material allows for the proximal slope to remain steeper than is typically reported, and it is not dramatically different from the distal slope. This contradicts Ballantyne's (1987) classification scheme where distal slopes are always much steeper than proximal slopes. However, this feature is not located at the talus base, as is typically reported; the proximal slope value is similar to values reported for ramparts with a mid-slope position (Shakesby et al., 1987) and within the range reported for protalus ramparts with similar parent material on Mt. Lassen (Pérez, 1990).

The boulders throughout this feature are significantly smaller than the lower elevation rock islands. Larger stones bounding over the rampart and continuing down to the cirque floor might explain this distribution of boulder sizes. The proximal side of this feature has the smallest range of boulder sizes, and there is a lack of fines suggesting both a minimum and maximum size threshold for particles being deposited on this feature.

The uniform distribution of $\mathrm{A}$ axis orientation on the proximal side of this feature is typical of protalus ramparts. However, the significant down slope orientation of boulders on the distal slope suggests there are additional processes at 
work on this feature. The height of this feature, measured from the base of the snow to the crest, varied from about $1 \mathrm{~m}$ in mid-August to $5 \mathrm{~m}$ in late September the following year. The feature is considered active, but this relatively large range in snow depth means very few boulders can come to rest on the distal side of the slope.

In the winter, the entire feature is snow covered, and most rockfall material would continue past the mid-slope position. During the summer and fall, any stone large enough to bounce over the feature would also continue down the steep slope. Thus, the distal side of this protalus rampart is probably remnant of a heavy snowfall period when a thicker perennial snowfield existed above the feature. Subsequently, the distal slope has degraded. Like many talus surfaces, as the material begins to slide and creep, the boulders assume a preferential down slope orientation (Rapp, 1960; Caine, 1967; Chandler, 1973; Pérez, 1988). Because of the unique placement of this feature, it is actively accumulating debris on its proximal side in a protalus rampart fashion and eroding material on its distal side much like a typical talus slope.

\section{Rock Island Features}

On Mt. Thielsen, there are numerous boulders, some in excess of $10 \mathrm{~m}$ across, strewn throughout the cirque floor. Based on the number of trees that have been topped and the impact scars on boulders, it appears rockfall is an important geomorphic process in this area. The rock islands in the cirque are likely the result of this rockfall. 
Relative accumulations of Mazama ash provide the best indicator of rock island formation. Beyond a depth of $70 \mathrm{~cm}$, each rock island is composed primarily of Mazama ash. The ubiquitous presence of ash argues against a glacial origin for the rock islands since there is no till at depth. The rock islands below the moraine and protalus rampart have developed chiefly through rockfall with the possible exception of rock island 7 .

The buried soil beneath a layer of angular clasts on rock island 7 records either a landslide/avalanche or a period of frequent sustained rockfall possibly following the over-steepening of the push-deformation moraine. The surface of this feature appears to be related to individual rockfall events. The inter-island areas have Mazama ash on the surface, and ash is present on all surfaces outside of the cirque.

On the surface of each rock island, there are boulders with fresh impact scars (Figure 15) and rock fragments from rockfall impact. Many trees on these features also have impact scars, and a few have been topped by rockfall (Figure 16). It appears rockfall may be an important disturbance agent in maintaining treeline. In addition, some groups of trees have been topped at the same height possibly by slab avalanching (Figure 17). 


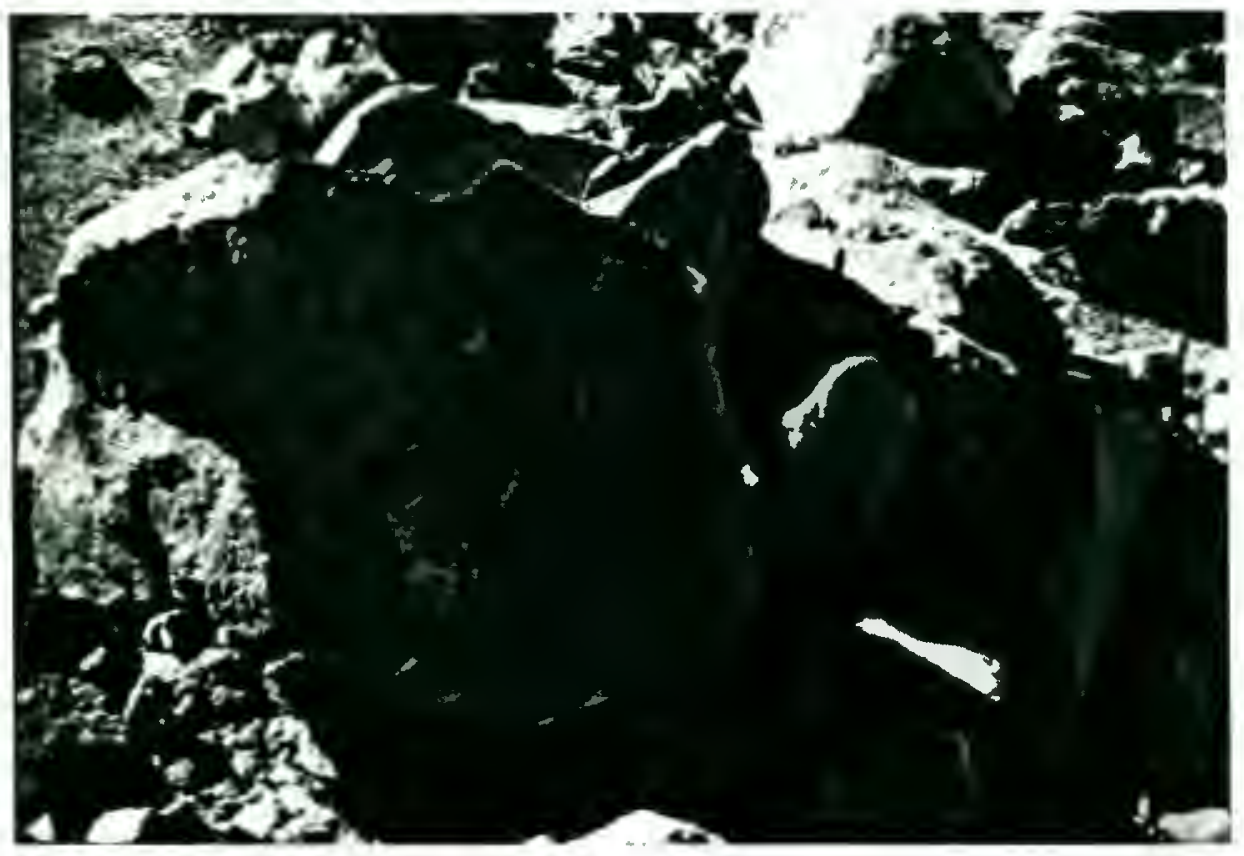

Figure 15. Typical impact scars found on rock island boulders.

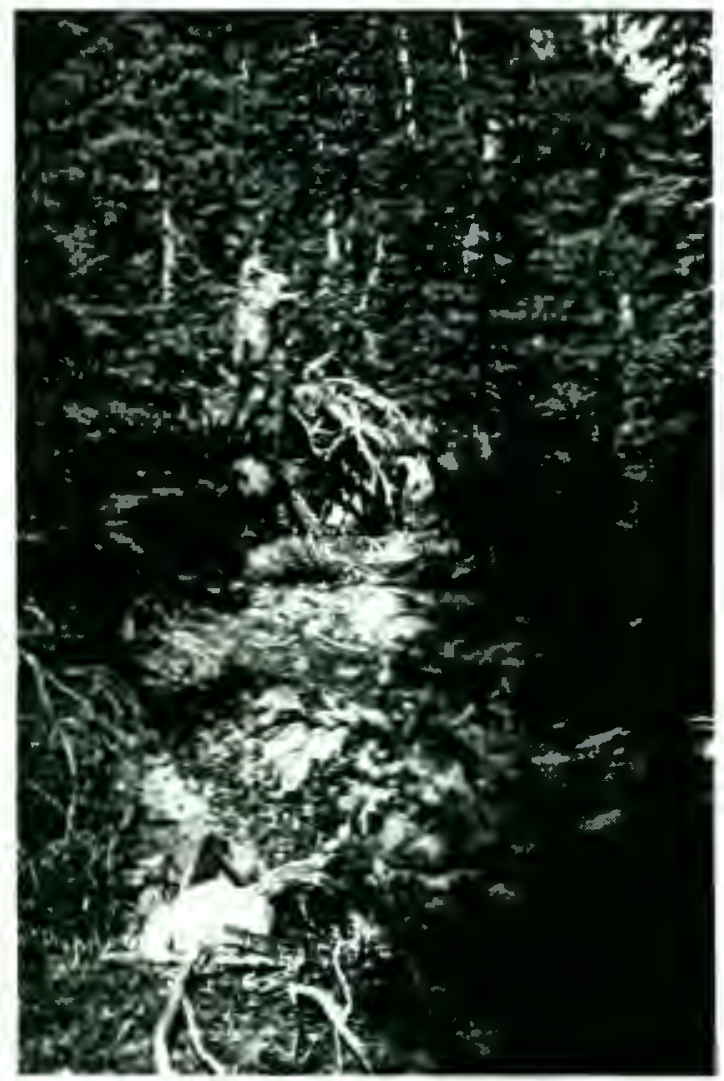

Figure 16. Tree on rock island topped by rockfall. 


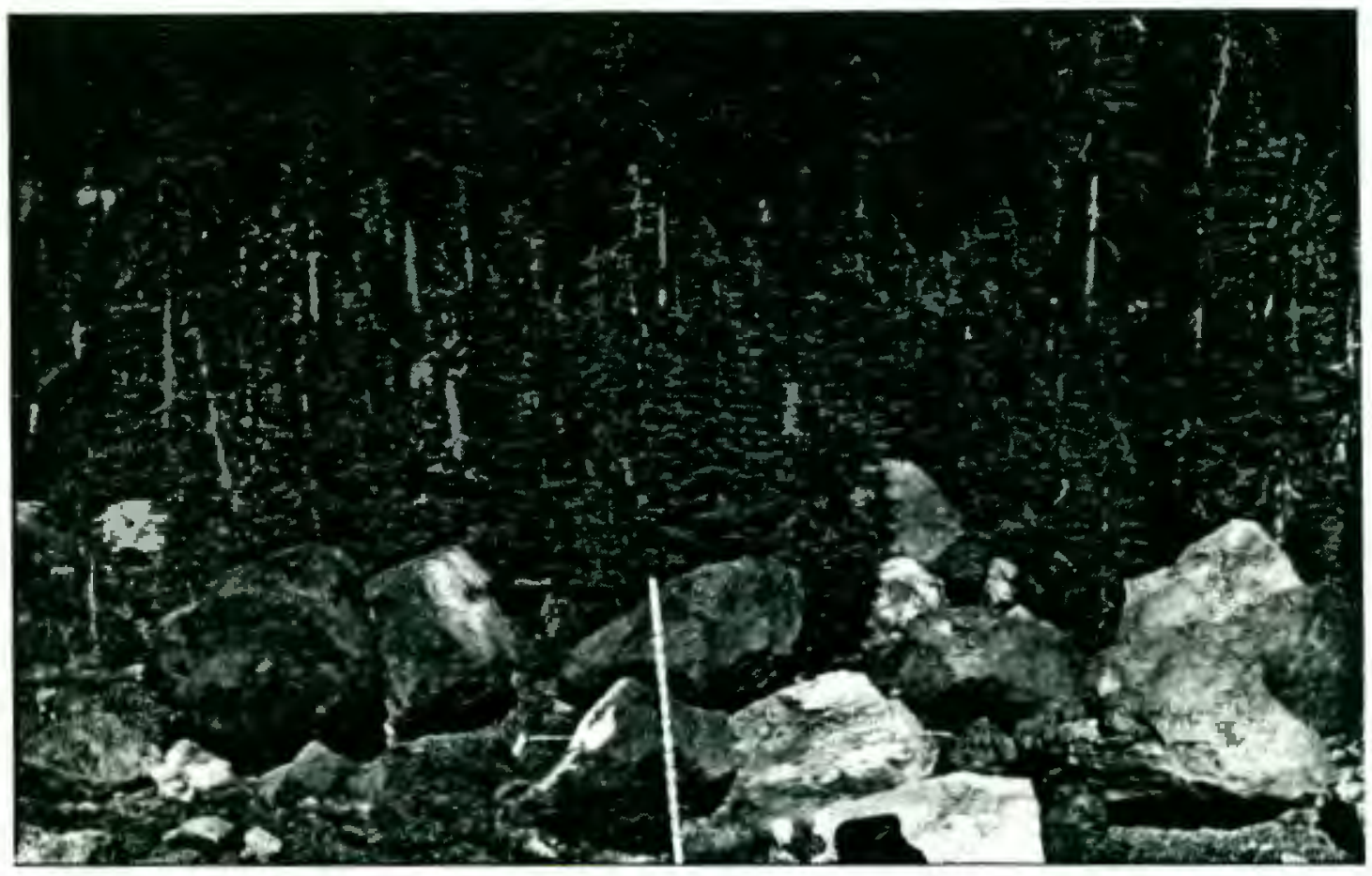

Figure 17. Stand of trees possibly topped by a slab avalanche.

The location of each feature represents preferential paths of rockfall. Large boulders in the inter-island areas are widely dispersed. Comparatively low stone frequencies for rock islands 6,7 , and 8 result from the larger boulders on these features. Their presence supports the idea that boulders have the ability to bound over the features near the glacier. The relatively higher frequency of boulders on rock island 5 is a function of its location directly beneath the active protalus rampart and an active talus slope. The protalus rampart provides a less effective barrier than the moraine, and the talus slope provides no barrier to falling rocks. None of the rock islands have significant orientations as is expected in a rockfall dominated environment. 


\section{FEATURE AGES}

Based on relative distance from the headwall, talus features in the cirque should increase in age from the highest elevation moraine to the lowest elevation rock island unless there was evidence for any crosscutting or superposition of material. The presence of Mazama ash provides a maximum age for features in the cirque. Ash underlies all features in the cirque indicating their development following the catastrophic eruption of Mt. Mazama 6800 YBP. Ash most likely buried the entire study area; excavations near Mt. Thielsen have ash deposits over $10 \mathrm{~m}$ thick (Bacon, 1983). As with other locations near the study area, the ash would have quickly eroded from steep slopes.

The lack of soil development, lichens, or significant vegetation implies either the moraine and protalus rampart are quite young or they have been under continuous snow cover throughout the Neoglacial. However, the absence of weathered boulders or cobbles with weathering rinds suggests the features are young. Although the presence of the glacier was not noted until 1966, it has probably existed throughout the Little Ice Age. Its late detection probably resulted from its extensive debris cover and inaccessibility. Scott (1977) separates the Little Ice Age deposits on Mt. Jefferson into Phase 1 and Phase 2 based on relative position. I propose that the establishment of the moraine on Mt. Thielsen correlates with Scott's Phase 1, and the mantling of the glacier and moraine with debris and protalus till correlates with Scott's Phase 2. I suggest these events be classified as the Lathrop 1 and Lathrop 2 Little Ice Age events on Mt. Thielsen. 
Soil profiles on each rock island indicate there has been significant redeposition of ash that coincided with continued rockfall events. However, the $70 \mathrm{~cm}$ depth marks the earliest period of mass-wasting activity since the eruption. Soil development on rock islands 6,7 , and 8 and the inter-island location is intermediate between the oldest dated Neoglacial deposits described in the Cascades and soils formed in post Wisconsin-age till (Scott, 1977; Mahaney et al., 1981). Hence, these soils have been developing since the deposition of Mazama ash. The soil above the landslide material on rock island 7 is similar to the oldest Neoglacial soil described by Mahaney et al. (1981) in the Washington Cascades. Lichen data suggest the rock islands are older than the moraine and protalus rampart but do not indicate a difference in surface ages between the rock islands.

\section{TRANSECT DATA}

If boulders on the cirque floor arrived at their present location through rockfall, I would expect there to be particle sorting down the transect, small to large, and there should be a uniform distribution of $A$ axis orientation. Sphericity has been shown to increase down slope in rockfall dominated environments due to the greater ability of spherical objects to roll downhill (Perez, 1986 and 2000). Thus, the sphericity values should increase down the transect, and flatness values should decrease.

If lichen sizes are randomly distributed along the transect, this should indicate stochastic rockfall events are the dominant process throughout the cirque. However, if there is a spatial grouping of lichen sizes along the transect, it may indicate discreet 
geomorphic events. Lichen data also provide relative ages for individual rockfall events.

The transect data support the hypothesis that rockfall is the dominant geomorphic process in the cirque but do not suggest a typical accumulation of talus. There is no significant sorting by boulder size along the transect as is seen on many talus slopes (Perez, 2000). The lower section exhibits a significant down slope orientation and is significantly less spherical than the upper and middle (upslope) sections. This is the inverse of what is described for most talus areas.

Without the moraine impeding rockfall, the cirque on Mt. Thielsen would resemble many of the other Cascade cirques showing no evidence of recent glacial activity (i.e., since the late-1800s). Prior to the Lathrop Glacier forming at the onset of the Little Ice Age, the study area probably resembled typical talus slope areas such as those formed on Mt. Washington in the central Oregon Cascades. However, with construction of the moraine, some talus material was impeded during its fall to the cirque floor.

Many observers note a particle size threshold for rocks bounding over a structural feature such as moraines or protalus ramparts. The largest boulders in the Mt. Thielsen transect are clustered in the middle section. The few large boulders $(>3$ m) with no lichens are located in this section. This suggests the middle section is currently the maximum distance most boulders typically travel in the cirque.

There also appears to be a threshold for the shape of a particle that can similarly bound over talus features. The amount of energy needed to propel an 
elongated or platy particle over the moraine would be higher than for a similarly sized spherical boulder. The significant accumulation of relatively smaller and less spherical boulders in the lower section of the transect suggests these stones were deposited prior to the construction of the moraine. Their relatively older age is further supported by the significant down slope orientation of $\mathrm{A}$ axes in this section resulting from creep and the occurrence of both the largest individual lichen diameter and the highest mean for the five largest lichens.

Assigning an age to any surface in the cirque is problematic. Since rockfall is the dominant process throughout the cirque, any area susceptible to rockfall is active. Certainly the moraine and protalus rampart are no older than the Little Ice based on a lack of lichens and the absence of soil development. Other features and surfaces in the cirque are younger than the Mazama eruption since ash underlies the entire cirque. Nonetheless, lichen covered boulders can be found immediately next to a completely fresh boulder of the same size at many locations in the cirque emphasizing the dynamic nature of the geomorphic processes affecting landform development on Mt. Thielsen.

\section{COMPARISON OF DEPOSITS AND METHODS}

Throughout the Oregon and Washington Cascades Little Ice Age deposits have small lichen sizes, little soil development, $100 \%$ fresh stones, high boulder frequencies, no weathering rinds, and are thinly vegetated. The data show a latitudinal gradient from Dome Peak, North Cascades to Mt. McLoughlin, southern Oregon 
Cascades where weathering characteristics and botanical indicators become less pronounced in more southerly locations (Table X; see Table I for correlations).

Maximum lichen sizes on Little Ice Age deposits decrease from $6.5 \mathrm{~mm}$ on Dome Peak (Miller, 1969) and $9 \mathrm{~mm}$ on Mt. Adams (Mahaney et al., 1981) to <2.5 mm on Mt. McLoughlin (Carver, 1972). No lichens were found on the Lathrop deposits for Mt. Thielsen. The Little Ice Age deposits on Dome Peak, Mt. Adams, and Mt. Hood occur below treeline; deposits on Mt. Jefferson are above treeline but have extensive ground cover. There is only sparse vegetation on Broken Top while deposits on Mt. Thielsen and Mt. McLoughlin are nearly barren of any vegetation.

All locations report $100 \%$ fresh stones and no weathering rinds on Neoglacial deposits since it takes up to 3000 years to develop detectable rinds on andesites and basalts (Colman and Pierce, 1984). Depth of soil development is more extensive on Mt. Adams $(31 \mathrm{~cm})$ and Mt. Hood $(25 \mathrm{~cm})$ than on Mt. Thielsen $(10 \mathrm{~cm})$ and Mt. McLoughlin (not oxidized). Boulder frequencies increase from $60 / 100 \mathrm{~m}^{2}$ on Mt. Adams to $100 / 100 \mathrm{~m}^{2}$ on Mt. Jefferson and $489 / 100 \mathrm{~m}^{2}$ on Mt. Thielsen. Moraines in the southem portion of the range are relatively closer to the cliff headwall, and protalus till is relatively more important. 
TABLE X

RELATIVE DATING RESULTS FROM NEOGLACIAL STUDIES IN THE

CASCADE RANGE

\begin{tabular}{|c|c|c|c|c|c|c|c|c|}
\hline & $\begin{array}{l}\text { Neoglacial } \\
\text { advance }\end{array}$ & $\begin{array}{l}\text { Dome } \\
\text { Peak, } \\
\text { WA }^{1}\end{array}$ & $\begin{array}{c}\text { Mount } \\
\text { Adams, } \\
\text { WA }^{2}\end{array}$ & $\begin{array}{l}\text { Mt. Hood, } \\
\text { OR }^{3}\end{array}$ & $\begin{array}{c}\text { Mt. } \\
\text { Jefferson, } \\
\text { OR }^{4}\end{array}$ & $\begin{array}{l}\text { Broken } \\
\text { Top, OR }{ }^{5}\end{array}$ & $\begin{array}{c}\text { Mt. } \\
\text { Thielsen, } \\
\text { OR }^{6}\end{array}$ & $\begin{array}{c}\text { Mt. } \\
\text { McLoughlin, } \\
\text { OR }^{7}\end{array}$ \\
\hline \multirow{2}{*}{$\begin{array}{l}\text { Maximum lichen } \\
\text { diameter }(\mathrm{mm})\end{array}$} & Late & 6.5 & 9 & $\sim$ & $\sim$ & $\sim$ & $\mathbf{0}$ & $<2.5$ \\
\hline & Early & $\sim$ & 26 & $\sim$ & * & $\sim$ & * & 10 \\
\hline \multirow[t]{2}{*}{$\begin{array}{l}\text { Boulder frequency } \\
\left(\text { per } 100 \mathrm{~m}^{2}\right)\end{array}$} & Late & $\sim$ & 60 & $\sim$ & 100 & $\sim$ & 489 & $\sim$ \\
\hline & Early & $\sim$ & 30 & $\sim$ & $*$ & $\sim$ & $*$ & $\sim$ \\
\hline \multirow{2}{*}{$\begin{array}{l}\text { Maximum weathering } \\
\text { rind (mm) }\end{array}$} & Late & $\sim$ & $<2$ & $\sim$ & $<1$ & $\sim$ & $<1$ & $\mathbf{0}$ \\
\hline & Early & $\sim$ & 2 & $\sim$ & * & $\sim$ & * & $<1$ \\
\hline $\begin{array}{l}\text { Depth of weathering } \\
\qquad(\mathrm{cm})\end{array}$ & Late & $\sim$ & 51 & 25 & $\sim$ & $\mathbf{0}$ & $10+$ & 0 \\
\hline Typical soil profile & $\begin{array}{l}\text { Early } \\
\text { Late } \\
\text { Early } \\
\end{array}$ & $\tilde{\sim}$ & $\begin{array}{c}76 \\
\text { Cox } \\
\text { A/Cox } \\
\end{array}$ & $\begin{array}{c}55 \\
\text { Cox } \\
\text { A/Cox } \\
\end{array}$ & * & $\begin{array}{c}30+ \\
\mathrm{Cu} \\
\mathrm{A} / \mathrm{Bw} / \mathrm{C} \\
\end{array}$ & 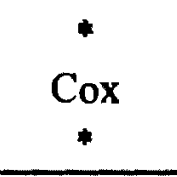 & $\underset{\sim}{\sim}$ \\
\hline
\end{tabular}

$\sim$ Not reported

*No deposits

(1-Miller, 1969; 2-Mahaney et al., 1981; 3-Lilliquist, 1989; 4-Scott, 1977; 5-Scott and Gardner, 1990; 6-this paper; 7-Carver, 1972) 
All of the aforementioned deposits are considered Little Ice Age based on relative position from the cirque headwall and degree of weathering characteristics. Although it is possible to roughly correlate all of these deposits, the variance in results emphasizes the need for more precise dating methods when assessing Neoglacial deposits. The boulder frequency is not a good indicator of age since it is skewed by distance from the headwall. Lichen diameters and vegetation cover can distinguish between different age deposits locally but do not appear useful for correlating regional patterns. Soil development and weathering rinds are effective at correlating across large spatial areas but lack temporally fine resolution and are not useful on young deposits.

The Lathrop deposits on Mt. Thielsen are most similar to the Broken Top and Mt. McLoughlin Little Ice Age deposits. However, the soils in the cirque below the moraine are more developed than early Neoglacial soils on Mt. Adams, Mt. Hood, Mt. Bachelor (Scott and Gardner, 1990), Broken Top, and Mt. McLoughlin. This indicates the surface has not been glaciated since the Mazama eruption and reinforces the argument that there are no deposits older than Little Ice Age on Mt. Thielsen.

The existence of a glacier on Mt. Thielsen is somewhat anomalous. The current ELA for Lathrop Glacier is about $2450 \mathrm{~m}$ if calculated using an accumulationarea ratio of 0.65. The ELAs for Mt. Jefferson, Broken Top, and Mt. Bachelor are all approximately $2600 \mathrm{~m}$ (Dethier, 1980; Scott, 1977; Scott and Gardner, 1990), and Mt. McLoughlin no longer has a glacier in its north cirque (Carver, 1972). 
Graf (1976) argues that under the current mild climatic conditions landform is a strong factor in the maintenance of cirque glaciers. According to Graf (1976, P. 79) "an optimum glacier location is in a large cirque, facing northeast, with a planimetric shape of width greater than length, high steep walls, a pass located to the windward, and a peak to the southwest." The north cirque of Mt. Thielsen meets each of these criteria. The Lathrop Glacier rarely receives direct sunlight; the narrow peak casts a shadow that covers the upper portion of the glacier at noon in late-July. Winter storms approach Mt. Thielsen from the southwest depositing snow and blowing drifts from the broad west slopes into the north cirque. The combination of shading in the summer and active rockfall providing a debris cover allows the Lathrop Glacier to persist below the regional ELA.

Glaciers form as more snow accumulates each year than melts. The current conditions allow for the persistence of Lathrop Glacier on Mt. Thielsen because of a net gain through snowfall, the favorable topographic conditions, and insulation from rockfall. If snowfall were to decrease and/or temperatures were to increase at Mt. Thielsen, the glacier would recede but a debris-covered glacier or rock glacier could persist. Temperatures were relatively cool in the early and middle Neoglacial (O'Brien et al., 1995), but it appears the climate was most severe in the Oregon Cascades during the Little Ice Age (Scott and Gardner, 1990). This may explain why smaller mountains with favorable cirque morphology in the Pacific Northwest such as Mt. Thielsen, Mt. Bachelor, and Three Fingered Jack apparently had their maximum Neoglacial advance most recently. There may have been early or middle Neoglacial 
features on Mt. Thielsen prior to the Little Ice Age, but the recent advance of the Lathrop Glacier has most likely buried them. 


\section{CHAPTER VII}

\section{CONCLUSIONS}

The Neoglacial history of Mt. Thielsen includes evidence for two periods of glacial and periglacial activity during the Little Ice Age, Lathrop 1 and Lathrop 2. In the initial advance, a terminal moraine and protalus rampart formed within $200 \mathrm{~m}$ of the cirque headwall. The retreat is recognized by an accumulation of protalus till on the moraine and renewed activity of the protalus rampart. The phases are correlative with the Phase 1 and Phase 2 Little Ice Age deposits on Mt. Jefferson, central Oregon Cascades.

Soils beyond the moraine are developed in Mazama ash and are more weathered than soils on early Neoglacial deposits elsewhere in the Cascades. Evidence for glacial activity on Mt. Thielsen before the Little Ice Age is absent or has been destroyed by the recent advance of the Lathrop Glacier. The cirque morphology, shape, and position of Mt. Thielsen's peak make this location ideal for snowfall accumulation and glacier maintenance. If snowfall were less before the Little Ice Age at Mt. Thielsen a rock glacier or debris-covered glacier could persist. Since there is no evidence for an early or middle Neoglacial feature on Mt. Thielsen, the Little Ice Age may represent a time when climatic conditions were more severe than at any other time in the Neoglacial for this location. 
Boulder shape, size, and orientation were useful diagnostic indicators of geomorphic process on Mt. Thielsen. Traditional taxonomic rules for separating moraines from protalus ramparts were not effective for the polygenetic pushdeformation moraine. For this reason, I recommend future research incorporate particle morphology and quantitative vector analyses when studying landforms produced by mass-wasting of varying frequencies and magnitudes.

Soil descriptions remain the best method for correlating Holocene deposits at different locations, and profile development indices are an important means of comparing relative rates of soil development. Weathering rinds do not provide the temporal resolution necessary for dating Neoglacial deposits on Mt. Thielsen, and surface stone frequency and abrasion ratios are problematic because fresh rockfall can come to rest on relatively older deposits. Lichenometry is best restricted to features within a particular cirque.

The Lathrop 1 and Lathrop 2 events are correlative with Little Ice Age deposits throughout the western cordillera. The ELA on Lathrop Glacier (approximately 2450 $\mathrm{m}$ ) is lower than the current regional ELA (approximately $2600 \mathrm{~m}$ ) and the glacier probably exists because of its preferential topographic position and extensive debris cover. This is a significant point for researchers interested in glacial dynamics and water resources. If annual snowfall decreases, the glacier will exist longer than a similar sized bare ice glacier. Conversely, a growing protalus rampart may indicate an increase in annual snowfall but not necessarily a decrease in annual temperatures. The 
lack of deposits on Mt. Thielsen of middle or early Neoglacial age may be a result of insufficient snowfall during those times to maintain or advance the Lathrop Glacier.

Future research in the Mt. Thielsen area should investigate the relationship between rockfall, avalanching, and treeline to assess the timing, magnitude, and return interval of these mass wasting disturbance events. There is also a unique opportunity to assess the rate and volume of mass-wasting for Mt. Thielsen since all material in the cirque is stratigraphically above a 6800 year old Mazama ash layer.

Many deposits formerly thought to be of early Neoglacial have been radiocarbon dated as Pleistocene in the Sierras and Rocky Mountains. This has complicated the Neoglacial chronologies in those locations and cast doubt on the usefulness of relative dating techniques in those areas. Future projects in the Oregon Cascades should attempt to find material suitable for radiocarbon dating on Mt. McLoughlin, Broken Top, and Mt. Jefferson to determine if the early Neoglacial deposits there are actually late Pleistocene. However, workers should continue to record the results of relative dating techniques in each of those areas so that absolute dating curves for lichen growth and weathering parameters can be constructed for use throughout the Oregon Cascades. 


\section{REFERENCES}

Alley, R. B., Mayewski, P. A., and Saltzman, E. S. 1999. Increasing north Atlantic climate variabiligy recorded in a central Greenland Ice Core. Polar Geography 23:119-131.

Allison, L. E. 1965. Organic carbon. Pp. 1367-1368. In: Black, A. (ed.). Methods of Soil Analysis, pt. II. American Society of Agronomy, Madison, WI.

Anderson, L. W. and Anderson, D. S. 1981. Weathering rinds on quartzarenite clasts as a relative age indicator and the glacial chronology of Mount Timpanogos, Wasatch Range, Utah. Arctic and Alpine Research 13:25-31.

Andrews, J. T. 1961. The development of scree slopes in the English Lake District and Central Quebec-Labrador. Cahiers de Geographie du Quebec 10:219-230.

Anonymous 1981. Oregon's southernmost glacier named for hypothermia expert. Oregon Geology 43:20.

Antevs, E. 1955. Geologic-Climatic dating in the west. American Antiquity 25:30-34.

Bacon, C. R. 1983. Eruptive history of Mount Mazama and Crater Lake caldera, Cascade Range, USA. Journal of Volcanology and Geothermal Research 18:57-115.

Ballantyne, C. K. 1987. Some observations on the morphology and sedimentology of two active protalus ramparts, Lyngen, northern Norway. Arctic and Alpine Research 19:167-174.

Ballantyne, C. K. and Kirkbridge, M. P. 1986. Characteristics and significance of some lateglacial protalus ramparts in upland Britain. Earth Surface Processes and Landforms 11:659-671.

Benedict, J. B. 1967. Recent glacial history of an alpine area in the Colorado Front Range, U.S.A., I. Establishing a lichen-growth curve. Journal of Glaciology 6:817-832.

Benedict, J. B. 1968. Recent glacial history of an alpine area in the Colorado Front Range, U.S.A., II. Dating the glacial deposits. Journal of Glaciology 7:77-87. 
Benedict, J. B. 1973. Chronology of cirque glaciation, Colorado Front Range. Quaternary Research 3:584-599.

Beschel, R. 1958. Lichenometrical studies in West Greenland. Arctic 11:254.

Birkeland, P. W. 1973. Use of relative age-dating methods in a stratigraphic study of rock glacier deposits, Mt. Sopris, Colorado. Arctic and Alpine Research 5:401-416.

Birkeland, P. W. 1999. Soils and Geomorphology, 3rd. edition. Oxford University Press, New York, NY.

Birkeland, P. W., Crandell, D. R., and Richmond, G. M. 1971. Status of correlation of Quaternary stratigraphic units in the western conterminous United States. Quaternary Research 1:208-227.

Blackwelder, E. B. 1931. Pleistocene glaciation in the Sierra Nevada and Basin Ranges. Geologic Society of America Bulletin 42:865-922.

Burke, R. M. and Birkeland, P. W. 1983. Holocene glaciation in the mountain ranges of the Western United States. Pp. 3-11. In: Wright, H. E. Jr., (ed.), Late-Quaternary Environments of the United States, Volume 2: The Holocene. University of Minnesota Press, Minneapolis, MN.

Büdel, J. 1982. Climatic Geomorphology. Princeton University Press, Princeton, N.J.

Burrows, R. A., Kovanen, D. J., Easterbrook, D. J., and Clark, D. H. 2000. Timing and extent of cirque glaciation near Mts Baker and Shuksan, North Cascade Range. Abstracts with Programs - Geological Society of America 32:7.

Butler, D. R. 1988. Neoglacial climatic inferences from rock glaciers and protalus ramparts, southern Lemhi Mountains, Idaho. Physical Geography 9:71-80.

Butler, D. R., Sorenson, C. J., Dort, W., Jr. 1984. Late Quaternary glacial sequence, east-central Lemhi Moutains, Idaho, USA. Pp. 423-435. In: Mahaney, W.C., (ed.). Correlation of Quaternary Chronologies. Geo Books, Norwich, England.

Caine, T. N. 1967. Texture of talus in Tasmania. Journal of Sedimentary Petrology 37:796-803.

Carver, G. A. 1972. Glacial Geology of the Mountain Lakes Wilderness and Adjacent Parts of the Cascade Range, Oregon. Ph.D. dissertation, University of Washington, Seattle. 
Chamberlin, T. C. 1897. Studies for students: The method of multiple working hypotheses. Journal of Geology 5:837-848.

Chandler, R. J. 1973. The inclination of talus, talus terraces and other slopes composed of granular materials. Journal of Geology 81:1-14.

Clark, D. H., Clark, M. M., and Gillespie, A. R. 1994. Debris-covered glaciers in the Sierra Nevada, California, and their implications for snowline reconstructions. Quaternary Research 41:139-153.

Clark, D. H. and Gillespie, A. R. 1997. Timing and significance of late-glacial and Holocene cirque glaciation in the Sierra Nevada, California. Quaternary International 38-39:21-38.

Colman, S. M. and Pierce, K. L. 1984. Correlation of Quaternary glacial sequences in the western United States based on weathering rinds and related studies. Pp. 437-453. In: Mahaney, W.C., (ed.). Correlation of Quaternary Chronologies. Geo Books, Norwich, England.

Cottam, W. P. and Curtis, J. T. 1956. Use of distance measures in phytosociological sampling. Ecology 37:451-460.

Crandell, D. R. 1969. Surficial geology of Mount Rainier National Park, Washington. U.S. Geological Survey Bulletin 1288.

Crandell, D. R. 1970. Late glacial and postglacial dacitic volcanism near Lassen peak, California. Abstracts with Programs - Geological Society of America 2:83-84.

Crandell, D. R. and Miller, R. D. 1974. Quaternary stratigraphy and extent of glaciation in the Mount Rainier region, Washington. U.S. Geological Survey Professional Paper 847.

Curray, J. R. 1956. The analysis of two-dimensional data. Journal of Geology 64:117-131.

Curry, R. R. 1969. Holocene climatic and glacial history of the central Sierra Nevada, California. Geological Society of America Special Paper 123:1-47.

Davis, P. T. 1988. Holocene glacier fluctuations in the American Cordillera. Quaternary Science Reviews 7:129-157. 
Davis, P. T. and Osborn, G. 1987. Age of pre-Neoglacial cirque moraines in the central North American Cordillera. Geographie Physique et Quaternaire 41:365-375.

Denton, G. H. and Karlen, W. 1973. Holocene climatic variations: Their pattem and possible cause. Quaternary Research 3:155-205.

Dethier, D. P. 1980. Reconnaissance study of Holocene glacier fluctuations in the Three Sisters area, Oregon. EOS Transactions, American Geophysical Union 61:69.

Dreimanis, A. 1989. Tills: Their genetic terminology and classification. Pp. $17-84$. In: Goldthwait, R. P. and Matsch, C. L., (ed.). Genetic Classification of Glaciagenic Deposits. A. A. Balkema Publishers, Rotterdam, Netherlands.

Easterbrook, D. J. 1993. Surface Processes and Landforms. Macmillan Publishing Company, New York, NY.

Fieldes, M. and Perrott, K. W. 1966. The nature of allophane in soils: Part threerapid field and laboratory test for allophane. New Zealand Journal of Science 9:623-629.

Galehouse, J. S. 1971. Sedimentation analysis. Pp. 69-87. In: Carver, R. E., (ed.), Procedures in Sedimentary Petrology. Wiley-Interscience, New York, NY.

Goudie, A. 1990. Geomorphological Techniques, $2^{\text {nd }}$. Edition. Unwin Hyman, London, England.

Graf, W. L. 1976. Cirques as glacier locations. Arctic and Alpine Research 8:79-90.

Hall, R. D. 1994. The record of glaciation in the middle Rocky Mountains during and after the last glacial maximum (LGM); an update. Abstracts with Programs Geological Society of America 26:511.

Harden, J. W. 1982. A quantitative index of soil development from field descriptions: Examples from a chronosequence in central Califormia. Geoderma 28:1-28.

Haugland, J. E. 1998. Soil Catenas on Glacial Moraines of the Central Oregon Cascades. Thesis, Portland State University, Portland, OR.

Heine, J. T. 1998. Extent, timing, and climatic implications of glacier advances Mount Rainier, Washington, U.S.A., at the Pleistocene/Holocene transition. Quaternary Science Reviews 17:1139-1148. 
Hill, M. 1977. Glaciers of Mt. Shasta. California Geology 30:75-80.

Innes, J. L. 1984. The optimal sample size in lichenometric studies. Arctic and Alpine Research 16:233-244.

Jenny, H. 1941. Factors of Soil Formation. McGraw-Hill, New York, NY.

Kiver, E. P. 1974. Holocene glaciation in the Wallowa Mountains, Oregon. In: Mahaney, W. C. (ed.) Quaternary Environments Proceedings of a Symposium: Geographical Monographs No. 5. York University, Toronto, Canada.

Konrad, S. K. and Clark, D. H. 1998. Evidence for an early Neoglacial glacier advance from frock glaciers and lake sediments in the Sierra Nevada, Califomia, U.S.A. Arctic and Alpine Research 30:272-284.

Krumbein, W. C. 1941. Measurement and geological significance of shape and roundness of sedimentary particles. Journal of Sedimentary Petrology 11:6472.

Lilliquist, K. D. 1989. Holocene Fluctuations of the Coe Glacier, Mt. Hood, Oregon. Thesis, Portland State University, Portland, OR.

Madsen, D. B. and Currey, D. R. 1979. Late Quaternary glacial and vegetation changes, Little Cottonwood Canyon area, Wasatch Mountains, Utah. Quaternary Research 12:254-270.

Mahaney, W. C. 1973a. Neoglacial chronology in the Fourth of July Cirque, central Colorado Front Range. Geological Society of America Bulletin 84:161-170.

Mahaney, W. C. 1973b. Neoglacial chronology in the Fourth of July Cirque, central Colorado Front Range: reply. Geological Society of America Bulletin 84:37673772 .

Mahaney, W. C., Fahey, B. D., and Lloyd, D. T. 1981. Late Quaternary glacial deposits, soils, and chronology, Hell Roaring Valley, Mount Adams, Cascade Range, Washington. Arctic and Alpine Research 13:339-356.

Mahaney, W. C. and Spence, J. 1984. Glacial and periglacial sequence and floristics in Jaw Cirque, central Teton Range, western Wyoming. American Journal of Science 284:1056-1081. 
Mangerud, J. 1987. The Alleroed/Younger Dryas boundary. Pp. 163-171. In: Berger, W. H. and Labeyrie, L. D. (eds.) Abrupt Climate Change. Kluwer Academic Publishers. Dordrecht, the Netherlands.

Matthews, J. A. 1994. Lichenometric dating; a review with particular reference to "Little Ice Age" moraines in Southern Norway. University of New Mexico Press, Albuquerque, NM.

McCabe, G. J., Fountain, A. G., and Dyurgerov, M. 2000. Variability in winter mass balance of northern hemisphere glaciers and relations with atmospheric circulation. Arctic, Antarctic, and Alpine Research 32:64-72.

Meentemeyer, V. 1989. Geographical perspectives of space, time, and scale. Landscape Ecology 3:163-173.

Meier, M. F. and Post, A. S. 1962. Recent variations in net mass budgets of glaciers in western North America. International Association of Scientific Hydrology Publications 58:63-67.

Miller, C. D. 1969. Chronology of Neoglacial moraines in the Dome Peak area, North Cascade, Washington. Arctic and Alpine Research 1:49-66.

Miller, C. D. 1973. Chronology of Neoglacial deposits in the northern Sawatch Range, Colorado. Arctic and Alpine Research 5:385-4000.

Nafziger, R. 1974. The geology of Mt. Thielsen: From Pliocene to present. The Geological Newsletter 40:73-75.

Nelson, R. L. 1954. Glacial geology of the Frying Pan River drainage, Colorado. Journal of Geology 62:325-343.

O'Brien, S. R., Mayewski, P. A., Meeker, L. D., Meese, D. A., Twickler, M. S., and Whitlow, S. I. 1995. Complexity of Holocene climate as reconstructed from a Greenland Ice Core. Science 270:1962-1964.

Odell, W. J. and Hopkins, K. D. 1995. Post-Pinedale glacial and periglacial deposits of the Lake Agnes Cirque, Never Summer Mountains, Colorado. Abstracts with Programs - Geological Society of America 27:50-51.

Orr, E. L. and Orr, W. N. 1999. Geology of Oregon, $5^{\text {th }}$ Edition. Kendall/Hunt Publishing Company, Dubuque, IA.

Pérez, F. L. 1986. Talus texture and particle morphology in a north Andean paramo. Zeitschrift fur Geomorphologie 30:15-34. 
Pérez, F. L. 1988. The movement of debris on a high Andean talus. Zeitschrift für Geomorphologie 32:77-99.

Pérez, F. L. 1990. Surficial talus fabric and particle gliding over snow on Lassen Peak, California. Physical Geography 11:142-153.

Pérez, F. L. 2000. Talus fabric, clast morphology, and botanical indicators of slope processes on the Chaos Crags (California Cascades), U.S.A. Geographie Physique et Quaternaire 52:1-22.

Petit, J. R., J. Jouzel, D. Raynaud, N. I. Barkov, J. M. Barnola, I. Basile, M. Bender, J. Chappellaz, M. Davis, G. Delayque, M. Delmotte, V. M. Kotlyakov, M. Legrand, V. Y. Lipenkov, C. Lorius, L. Pépin, C. Ritz, E. Saltzman, and M. Stievenard. 1999. Climate and atmospheric history of the past 420,000 years from the Vostok ice core, Antarctica. Nature 399:429-436.

Porter, S. C. 1975. Weathering rinds as a relative-age criterion; application to subdivision of glacial deposits in Geology 3:101-104.

Porter, S. C. and Denton, G. H. 1967. Chronology of Neoglaciation in the North American cordillera. American Journal of Science 265:177-210.

Purdom, W. B. 1966. Fulgurites from Mount Thielsen, Oregon. Ore Bin 28:153-159.

Rapp, A. 1960. Recent development of mountain slopes in Kärkevagge and surroundings, north Scandinavia. Geografiska Annaler 42:65-200.

Rayleigh, L. 1894. The Theory of Sound, $2^{\text {nd }}$. Edition, vol. 1. Dover Publications, New York, NY.

Richmond, G. M. 1962. Quaternary stratigraphy of the La Sal Mountains, Utah. U.S. Geological Survey Professional Paper 324.

Schumm, S. A. 1991. To Interpret the Earth: Ten Ways To Be Wrong. Cambridge University Press, Cambridge, United Kingdom.

Schumm, S. A. and Lichty, R. W. 1965. Time, space, and causality in geomorphology. American Journal of Science 2263:110-119.

Scott, W. E. 1977. Quaternary glaciation and volcanism, Metolius River area, Oregon. Geological Society of America Bulletin 88:113-124. 
Scott, W. E. and Gardner, C. A. 1990. Field trip guide to the central Oregon High Cascades, Part 1: Mount Bachelor-South Sister area. Oregon Geology 42:99114.

Shakesby, R. A. 1997. Pronival (protalus) ramparts: a review of forms, processes, diagnostic criteria and palaeoenvironmental implications. Progress in Physical Geography 21:394-418.

Shakesby, R. A., Alastair, G. D., and Matthews, J. A. 1987. Rock glaciers, protalus ramparts and related phenomena, Rondane, Norway: A continuum of largescale talus-derived landforms. Boreas 16:305-317.

Sharp, R. P. 1969. Semi-quantitative differentiation of glacial moraines near Convict Lake, Sierra Nevada, Califomia. Journal of Geology 77:68-71.

Sherrod, D. V. 1990. Volcanoes of Oregon. Pp. 169-211. In: Wood, C. A. and Kienle, J., (eds.). Volcanoes of North America: United States and Canada. Cambridge University Press, Cambridge, G.B.

Soil Survey Staff, 1999. Keys to Soil Taxonomy, 8th edition. Pocahontas Press, Inc., Blacksburg, VA.

Sokol, R. R. and Rohlf, F. J. 1995. Biometry: The Principles and Practice of Statistics in Biological Research, $3^{\text {rd }}$. Edition. W. H. Freeman and Company, New York, NY.

Stork, A. 1963. Plant immigration in front of retreating glaciers, with examples from the Kebnekajse area, northern Sweden. Geografiska Annaler Series A 45:1-22.

Taylor, E. M. 1981. Road log for Central High Cascade geology, Bend, Sisters, McKenzie Pass, and Santiam pass, Oregon. Pp. 55-58. In: Johnston, D. A. and Donnelly-Nolan, J. M. (eds.). Guides to Some Volcanic Terranes in Washington, Idaho, Oregon, and Northern California. U. S. Geological Survey Circular 838.

Tonkin, P. J. and Basher, L. R. 1990. Soil-stratigraphic techniques in the study of soil and landform evolution across the Southern Alps, New Zealand. Geomorphology 3:547-575.

USDA, 1972. Soil Survey Laboratory Methods and Procedures for Collecting Soil Samples. USDA Soil Conservation Service, Soil Survey Illustrations Report No. 1. Procedure 8cla. 
Vincent, K. R. and Chadwick, O. A. 1994. Synthesizing bulk density for soils with abundant rock fragments. Soil Science Society of America Journal 58:455464.

Warren, W. P. 1989. Protalus till. Pp. 145-147. In: Goldthwait, R. P. and Matsch, C. L., (ed.). Genetic Classification of Glaciagenic Deposits. A. A. Balkema Publishers, Rotterdam, Netherlands.

Washburn, A. L. 1980. Geocryology: A Survey of Periglacial Processes and Environments. Halsted Press, New York, NY.

Western Regional Climate Center 1999. Station No. 351946, Crater Lake National Park.

Williams, H. 1933. Mount Thielsen, a dissected Cascade volcano. Pp. 195-213. In: Louderback, G. D., Chaney, R. W., and Williams, J. (eds.). University of California Publications, Department of Geological Sciences Bulletin, Volume 23. University of California Press, Berkeley, CA.

Williams, J. 1973. Neoglacial chronology in the Fourth of July Cirque, central Colorado Front Range: discussion. Geological Society of America Bulletin 84:3761-3766.

Yount, J. C., Birkeland, P. W., and Burke, R. M. 1979. Glacial and periglacial deposits of the Mono Creek recesses, west-central Sierra Nevada, California: Measurement of age-dependent properties of the deposits. Pp. 1-18. In: Burke, R. M. and Birkeland, P. W., (eds.). Field Guide to Relative Dating Methods Applied to Glacial Deposits in the Third and Fourth Recesses and along the Eastern Sierra Nevada, California, with Supplementary Notes on Other Sierra Nevada 'Localities.' Field Trip Guidebook for the Friends of the Pleistocene, Pacific Cell. 